Research Article

\title{
Performance of Retrofitted Self-Compacting Concrete-Filled Steel Tube Beams Using External Steel Plates
}

\author{
Ahmed A. M. AL-Shaar $\mathbb{I D}^{1,2}$ and Mehmet Tolga Göğüş (iD ${ }^{1}$ \\ ${ }^{1}$ Civil Engineering Department, University of Gaziantep, 27310 Gaziantep, Turkey \\ ${ }^{2}$ Civil Engineering Department, AL-Nahrain University, 10072 Baghdad, Iraq \\ Correspondence should be addressed to Ahmed A. M. AL-Shaar; ahmedcst77@gmail.com
}

Received 4 December 2017; Accepted 11 February 2018; Published 27 March 2018

Academic Editor: Hongchao Kou

Copyright (c) 2018 Ahmed A. M. AL-Shaar and Mehmet Tolga Göğüş. This is an open access article distributed under the Creative Commons Attribution License, which permits unrestricted use, distribution, and reproduction in any medium, provided the original work is properly cited.

\begin{abstract}
Self-compacting concrete-filled steel tube (SCCFST) beams, similar to other structural members, necessitate retrofitting for many causes. However, research on SCCFST beams externally retrofitted by bolted steel plates has seldom been explored in the literature. This paper aims at experimentally investigating the retrofitting performance of square self-compacting concrete-filled steel tube (SCCFST) beams using bolted steel plates with three different retrofitting schemes including varied configurations and two different steel plate lengths under flexure. A total of 18 specimens which consist of 12 retrofitted SCCFST beams, three unretrofitted (control) SCCFST beams, and three hollow steel tubes were used. The flexural behaviour of the retrofitted SCCFST beams was examined regarding flexural strength, failure modes, and moment versus deflection curves, energy absorption, and ductility. Experimental results revealed that the implemented retrofitting schemes efficiently improve the moment carrying capacity and stiffness of the retrofitted SCCFST beams compared to the control beams. The increment in flexural strength ranged from $1 \%$ to $46 \%$. Furthermore, the adopted retrofitting schemes were able to restore the energy absorption and ductility of the damaged beams in the range of $35 \%$ to $75 \%$ of the original beam ductility. Furthermore, a theoretical model was suggested to predict the moment capacity of the retrofitted SCCFST beams. The theoretical model results were in good agreement with the test results.
\end{abstract}

\section{Introduction}

Concrete-filled steel tube (CFST) members have been used over the world for high-rise buildings, bridges, and other structures involving very large applied moments, particularly in zones of high seismic risk [1-5]. CFST members provide several merits over the conventional tubular or reinforced concrete members, including high strength and stiffness, fire resistances, large energy absorption capacities, and favourable ductility $[6,7]$.

In the last years, self-compacting concrete (SCC) arrived as a revolution in the field of concrete technology. SCC was originated in Japan in the eighties and then spread to other countries [8-10]. SCC is a high-performance concrete that can discharge under its weight and fill in the formwork without any compaction efforts and without showing defects due to segregation and bleeding. Hence, reduces the noise level and construction time and cost, whereas still achieving good compaction [11]. Since the steel tubes have confined sections, SCC has a high potential to be the most appropriate concrete type in CFST members to secure that the best compaction is provided without any further precautions [12]. The adoption of SCC in CFST members can enhance the constructional quality of concrete, hence ensuring the performance of these composite members. The past experimental research revealed that the behaviour of CFST members filled with SCC is similar to those filled with normal concrete $[13,14]$.

Similar to other structural members, CFST members may necessitate retrofitting or upgrading for various causes. For instance, CFST members may require being repaired because of degradation due to environmental factors, fire, ageing, and earthquake accidents. Also, they may request strengthening in order to increment the load-carrying capacity or to recover the desired structural behaviour due to design faults, constructional errors, updating of design standard, and modification in the practical usage [15-21]. 
Hence, CFST members may need to be retrofitted or substituted to compensate for the inadequate capacity.

Fundamentally, there are two different techniques available for external retrofitting of the structural member. The first method is to attach steel plates to the external surfaces of the structural members [16-18, 22-24]. However, the second method is to bond advanced composite materials, such as carbon fiber-reinforced polymers (CFRPs) [15, 19-21, 25-29].

Recently, the applications of FRP composites in civil structures have been more acceptable due to their higher strength, higher stiffness, and low weight compared to steel plates $[20,21]$. Nevertheless, there are some disadvantages regarding the implementation of FRP materials. For example, the cost of these materials is still relatively high besides the need for skilled labour [17, 22, 30]. Furthermore, there are uncertainties regarding the long-term performance of these materials and the bonding between the composite materials and steel $[20,26,27]$. On the other hand, the implementation of external steel plating is a prevalent successful retrofitting method that was widely experienced in practice [22, 27]. The advantages of this method include the convenience and relative simplicity of application, the wide availability and low prices of the steel material, and the ductile behaviour and high deformation capacity of the steel plates compared to the composite materials which characterized by brittle nature $[17,22]$. In this research, the external steel plating method was used which is expected to increment or recover the flexural strength and stiffness of the SCCFST beams, reducing their service-load deflection and behaving in a ductile manner.

Search in the available literature revealed that many research works had been done on the strengthening and repair of CFST beams. However, most of these investigations have been performed on normal CFST beams, which externally retrofitted by CFRP laminates (e.g., [19-21, 27]). On the contrary, studies that examined the behaviour of SSCFST beams retrofitted with bolted steel plate are too scarce. However, there are many studies that have been conducted on reinforced concrete beams strengthened by steel plates (e.g., [16-18, 22, 30-33]).

$\mathrm{Al}$ Zand et al. [21] presented an experimental study on the strengthening performance of circular and rectangular CFST beams using unidirectional CFRP sheets. The results demonstrated that the moment carrying capacity, energy absorption capacity, and flexural stiffness of the strengthened beams considerably enhanced with the increase of CFRP layers. Sundarraja and Prabhu [27] experimentally examined the suitability of CFRP fabrics in the external strengthening of square CFST beams. Results indicated that the flexural strength and stiffness of the strengthened beams incremented when the number of CFRP layers was increased except in the case of beams strengthened by partial wrapping. On the other hand, the ductility index decreased as the number of CFRP layers increased.

Peng et al. [17] studied the behaviour of damaged rectangular reinforced concrete (RC) beams strengthened by bolted steel plates considering the effect of corrosion. The test results showed that adopting bolted steel plates in strengthening enhances the strength and ductility of the retrofitted beams. Also, it was found that the maximum load of strengthened damaged beams increased as the steel plate thickness increased. Aykac et al. [22] experimentally investigated the flexural strengthening and repair behaviour of rectangular RC beams retrofitted using external bolted steel plates. The results revealed that the ductility of the tested beams increased as the plate thickness decreased. The experiments proved that the anchorage of steel plates to the beams using steel bolts was a useful technique for obtaining sufficient strength and ductility and preclude the premature peeling failure of the plates in beams strengthened by thick solid plates.

\section{Research Significance and Objectives}

In view of the literature above, it can be concluded that research in the field of SCCFST beam retrofitted with external bolted steel plates is still rarely found in the literature. Furthermore, up to the best knowledge of the authors, no any previous study was carried out on the retrofitting of SCCFST beams with external steel plates. Therefore, it is evident that the research in this field is still in the primary stage and far from sufficient, especially if the differences in mechanical properties between the steel plates and the FRP composites were taken into consideration. More efforts are required in this field to fill this gap in the literature, to provide a better understanding of the flexural behaviour of such retrofitted composite beams, and to provide novel experimental information for the engineering practice. Therefore, the primary aims of this study are threefold: first, to generate novel new test data on the retrofitting of SCCFST beams with bolted steel plates; second, to investigate experimentally the flexural performance of retrofitted SCCFST beams regarding moment resistance, failure modes, ductility, and moment versus deflection curves; and finally, to examine the effect of the different parameter on the flexural behaviour of retrofitted SCCFST beams, such as different steel plate arrangements and lengths including full and partial retrofitting schemes.

\section{Experimental Investigation}

\subsection{Material Properties}

3.1.1. Self-Compacting Concrete (SCC). In this research, selfcompacting concrete (SCC) was adopted as infill material due to its superior workability. The mix design is prepared to attain a targeted compressive strength of $50 \mathrm{MPa}$ with a water to binder (cement and fly ash) ratio of 0.33 . The adopted SCC mix was prepared with a binder material consisting of the Portland cement PC (CEM I 42.5R) and fly ash (class F). The river gravel was used as a coarse aggregate with $12 \mathrm{~mm}$ maximum particle size. While, the fine aggregate was a mixture of river sand and crushed sand with a maximum size of $4 \mathrm{~mm}$ and $2 \mathrm{~mm}$, respectively. Finally, superplasticizer (Glenium 51) was adopted to obtain the required workability of the SCC mix. The mix proportions of the SCC are given in Table 1.

In order to assess and check the workability properties of the adopted SCC, the fresh characteristics of SCC were examined by slump flow and V-funnel tests, according to the EFNARC committee recommendations [34]. The slump flow test represents a substantial check for the flowability of 
TABLE 1: Mix proportions and properties of self-compacting concrete (SCC).

\begin{tabular}{lcccccrrr}
\hline $\begin{array}{l}\text { Cement } \\
\left(\mathrm{kg} / \mathrm{m}^{3}\right)\end{array}$ & $\begin{array}{c}\text { Fly ash } \\
\left(\mathrm{kg} / \mathrm{m}^{3}\right)\end{array}$ & $\begin{array}{c}\text { Coarse aggregate } \\
\left(\mathrm{kg} / \mathrm{m}^{3}\right)\end{array}$ & $\begin{array}{c}\text { River sand } \\
\left(\mathrm{kg} / \mathrm{m}^{3}\right)\end{array}$ & $\begin{array}{c}\text { Crushed sand } \\
\left(\mathrm{kg} / \mathrm{m}^{3}\right)\end{array}$ & $\begin{array}{c}\text { Water } \\
\left(\mathrm{kg} / \mathrm{m}^{3}\right)\end{array}$ & $\begin{array}{c}\text { SP } \\
\left(\mathrm{kg} / \mathrm{m}^{3}\right)\end{array}$ & $\begin{array}{c}f_{\mathrm{c}}^{\prime} \\
(\mathrm{MPa})\end{array}$ & $\begin{array}{c}\text { Density } \\
\left(\mathrm{kg} / \mathrm{m}^{3}\right)\end{array}$ \\
\hline 430 & 140 & 730 & 670 & 223 & 188.1 & 3.00 & 59.48 & 2378.57 \\
\hline
\end{tabular}

TABLE 2: Workability characteristics of self-compacting concrete (SCC).

\begin{tabular}{lcc}
\hline Tests & Result & Workability classes \\
\hline Slump flow diameter $(\mathrm{DF})(\mathrm{mm})$ & 650 & SF1 $(550-650)$ \\
Slump flow time $\left(T_{50}\right)($ seconds) & 2.5 & VS2/VF2 $(>2)$ \\
V-funnel flow time $\left(V_{\mathrm{f}}\right)$ (seconds) & 8.5 & VS2/VF2 $(>8)$ \\
\hline
\end{tabular}

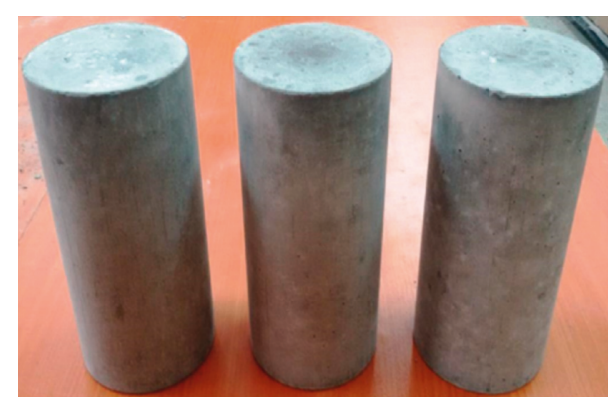

(a)

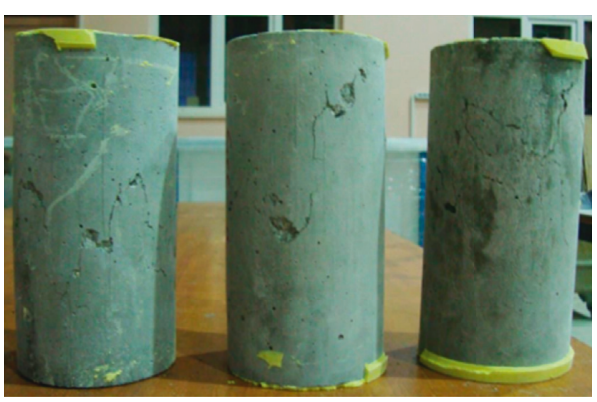

(b)

Figure 1: (a) Concrete cylinders before testing. (b) Concrete cylinders after testing.

SCC in unconfined zones, segregation resistance, uniformity of the fresh SCC mix, and the consistency to satisfy the specification. On the other hand, the $\mathrm{V}$-funnel test describes the viscosity and deformability of SCC.

The workability characteristics of the fresh SCC mixture used in this research are listed in Table 2, together with the limitations of the EFNARC committee [34].

Three self-compacting concrete cylinders $(100 \times 200 \mathrm{~mm})$ were cast and cured in water for 28 days and tested at the same time of the corresponding beam specimens as shown in Figure 1 . The concrete cylinder samples were tested according to the ASTM C39/C39M-14a standard [35]. At the test day, the average cylinder compressive strength of concrete was determined as $59.48 \mathrm{MPa}$.

3.1.2. Steel Tubes. This study includes 18 beam specimens divided into three groups. All the steel tubes were made from

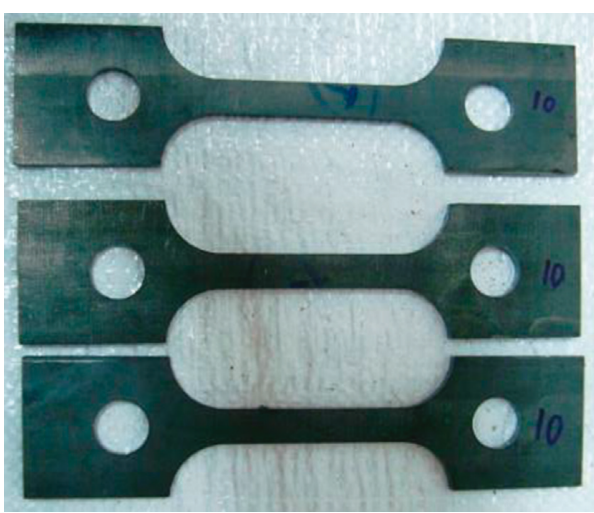

FIgURE 2: Steel coupon specimen.

Table 3: Properties of steel tubes.

\begin{tabular}{lccc}
\hline $\begin{array}{l}\text { Group } \\
\text { name }\end{array}$ & $\begin{array}{c}\text { Tube cross section } \\
B \times H \times t(\mathrm{~mm})\end{array}$ & $\begin{array}{c}\text { Yield strength } \\
\left(f_{\mathrm{y}}\right)(\mathrm{MPa})\end{array}$ & $\begin{array}{c}\text { Ultimate strength } \\
\left(f_{\mathrm{u}}\right)(\mathrm{MPa})\end{array}$ \\
\hline $\mathrm{A}$ & $100 \times 100 \times 3$ & 287.52 & 382.17 \\
$\mathrm{~B}$ & $100 \times 100 \times 3$ & 288.97 & 381.72 \\
C & $100 \times 100 \times 3$ & 285.53 & 377.64 \\
\hline
\end{tabular}

Table 4: Properties of steel plates.

\begin{tabular}{lcc}
\hline $\begin{array}{l}\text { Steel plate } \\
\text { thickness }(\mathrm{mm})\end{array}$ & $\begin{array}{c}\text { Yield strength } \\
\left(f_{\mathrm{y}}\right)(\mathrm{MPa})\end{array}$ & $\begin{array}{c}\text { Ultimate strength } \\
\left(f_{\mathrm{u}}\right)(\mathrm{Mpa})\end{array}$ \\
\hline 3.0 & 322.32 & 436.95 \\
\hline
\end{tabular}

three cold-formed square hollow sections with $6 \mathrm{~m}$ length. The nominal dimensions of the square steel tube sections were $100 \times 100 \times 3 \mathrm{~mm}$. Three coupons from each tube were cut from the three faces of the hollow steel sections to determine the actual material properties as shown in Figure 2.

Tensile coupon tests were performed and tested according to the recommendations of ASTM E8/E8M-15a [36]. The average yield and ultimate tensile stress for the steel tubes are listed in Table 3.

3.1.3. Steel Plates and Bolts. Rectangular steel plates with nominal thicknesses of $3 \mathrm{~mm}$ were used for the retrofitting of the SCCFST beams. The steel plates had a width of $94 \mathrm{~mm}$ and fabricated with two different lengths, $925 \mathrm{~mm}$ and $300 \mathrm{~mm}$, respectively. Similar to the steel tubes, three coupons were taken from the adopted steel plates to conduct the tensile coupon according to the recommendations of ASTM E8/E8M-15a [36]. The average yield and ultimate tensile stress for the steel plates are listed in Table 4.

All of the steel plates were drilled with an electrical rotary drill to produce two rows of circular holes distributed in 


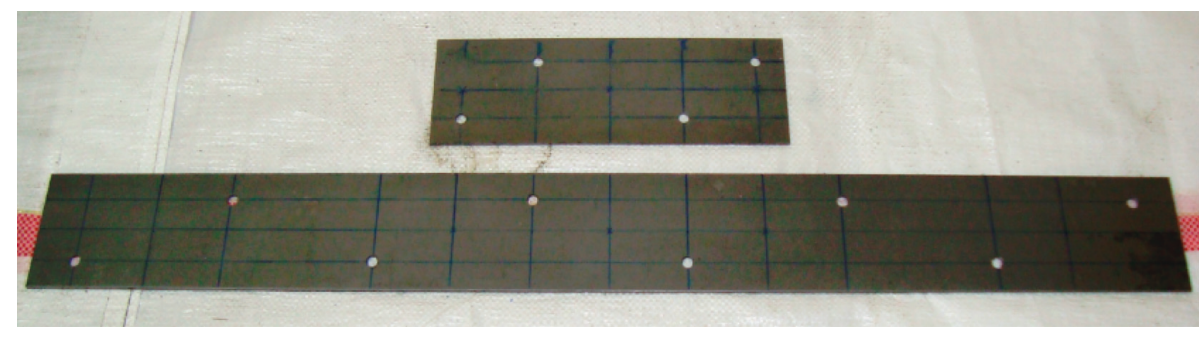

FIGURE 3: Typical perforated steel plates.

TABle 5: Properties of bolts.

\begin{tabular}{lcccc}
\hline Bolt type & $\begin{array}{c}\text { Diameter } \\
(\mathrm{mm})\end{array}$ & $\begin{array}{c}\text { Length } \\
(\mathrm{mm})\end{array}$ & $\begin{array}{c}\text { Yield strength } \\
(\mathrm{MPa})\end{array}$ & $\begin{array}{c}\text { Tensile strength } \\
(\mathrm{MPa})\end{array}$ \\
\hline Grade 8.8 & 6.3 & 40 & 640 & 800 \\
Grade 12.9 & 7.9 & 45 & 1100 & 1220 \\
\hline
\end{tabular}

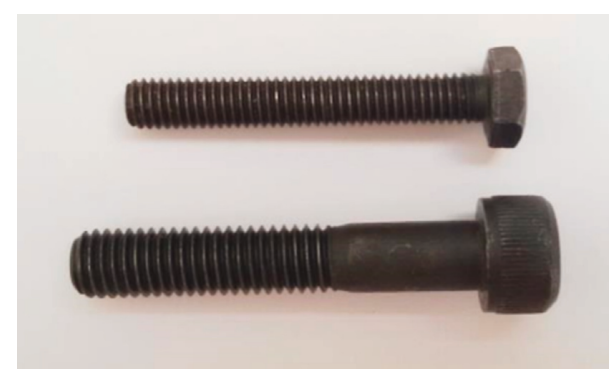

Figure 4: Typical bolts.

a staggered manner. All holes were performed with a suitable diameter and the center to center distance between holes was $125 \mathrm{~mm}$ and $50 \mathrm{~mm}$, in the longitudinal and transverse directions, respectively. Figure 3 depicts the perforated steel plates.

Two types of bolts were utilized in this work. Grade 8.8 and 12.9 threaded bolts were used to fasten the steel plates to the bottom and top faces of the SCCFST beams. The details and mechanical properties of these bolts are presented in Table 5. Figure 4 shows photos of typical anchor bolts adopted for retrofitting.

3.2. Specimen Preparation. The three cold-formed steel tubes of six meters long were cut and machined to the desired length. The total span of each beam specimen is $950 \mathrm{~mm}$ with an effective span of $750 \mathrm{~mm}$ between the end supports. The inside faces of the beam specimens were brushed and cleaned out. The bottom ends of the hollow steel tubes were capped with suitable steel base plates, the SCC was poured from the top without applying any compaction, and the steel tubes were kept in a vertical position for a curing period of 28 days. After that, the SCC surface at the top end of the beam was smoothed with epoxy coating and welded with a steel base plate to form complete composite beams. Holes with a suitable diameter were predrilled through the steel flanges and the concrete core of the SCCFST beams. These predrilled holes were executed at the locations where the retrofitting steel plates were required to be anchored. The inside of the predrilled holes was cleaned carefully using air to get rid of any dust or loose parts. Epoxy resin with highstrength properties was used to fill the constructed holes partially. Then, the predrilled steel plates were attached to be coinciding with the beam flanges. Finally, the steel bolts were installed in the holes and fastened tightly to hold and anchor the steel plates firmly to the beam flanges. Figure 5 depicts the different stages of drilling and anchoring of steel plates to the SCCFST beams.

3.3. Beams and Retrofitting Scheme Details. A total of 18 beam specimens of square sections were prepared for testing in this study. The 18 beams consist of 12 SCCFST beams retrofitted with steel plates with two different lengths and three distinct retrofitting schemes, three SCCFST beams without any strengthening (control beams) for comparison purposes, and three hollow steel tube beams. The 12 retrofitted SCCFST beams were also divided into two branches. 6 SCCFST beams prepared as intact (not preloaded) beams. These beams were strengthened with steel plates and bolts (grade 8.8 bolts) and then tested without any preloading. These beams aim at exploring the influence of drilling holes in the body of the SCCFST beams on both the steel tube and concrete. On the other hand, the remaining 6 SCCFST beams were considered as retrofitted (preloaded) beams. That is to say, these beams were initially preloaded up to a certain level, to simulate the damage condition. After that, the retrofitting techniques including the steel plates and bolts (grade 12.9 bolts) were applied to these beams before their testing.

The beam specimens were classified into three different groups A, B, and C. These groups represent three different retrofitting schemes. Each group consists of five beams, namely, one hollow beam, one control beam, two intact beams, and two retrofitted beams. The dimensions and details of each beam specimen are listed in Table 6. Regarding group A beams, the retrofitting technique was achieved using external single steel plates applied to the bottom face of the SCCFST beams. On the other hand, beams of group B were retrofitted using external steel plates anchored to the top and bottom surfaces of the SCCFST beams. Finally, double steel plates were fastened to the bottom face of the SCCFST beams in group C.

Moreover, in each group, the retrofitting technique was utilized using two different steel plate lengths: full retrofitting length in which the steel plate was attached to the full length of the SCCFST beams and partial length in which the steel plates 


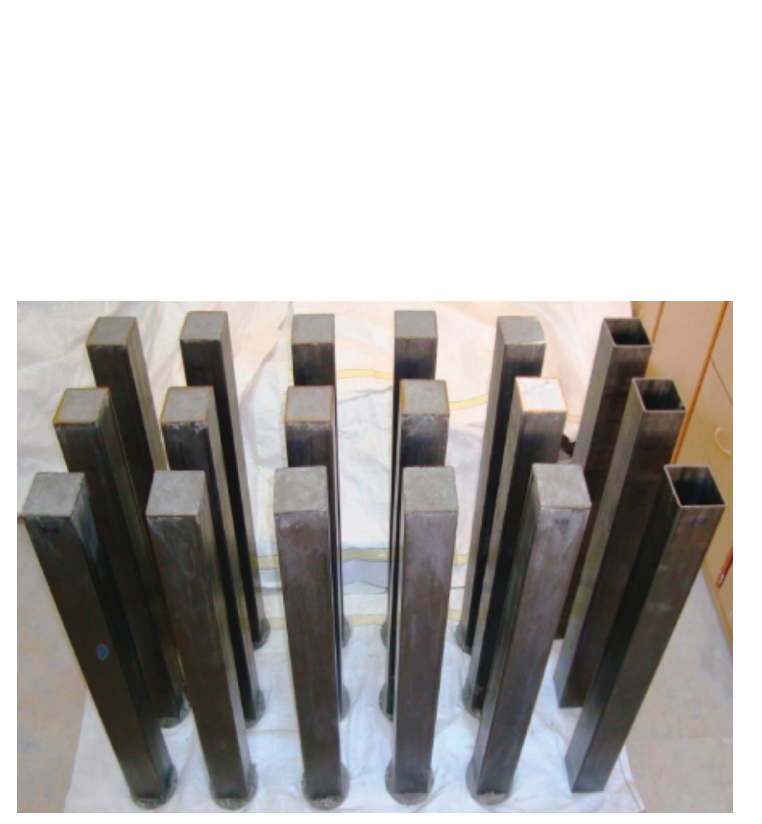

(a)

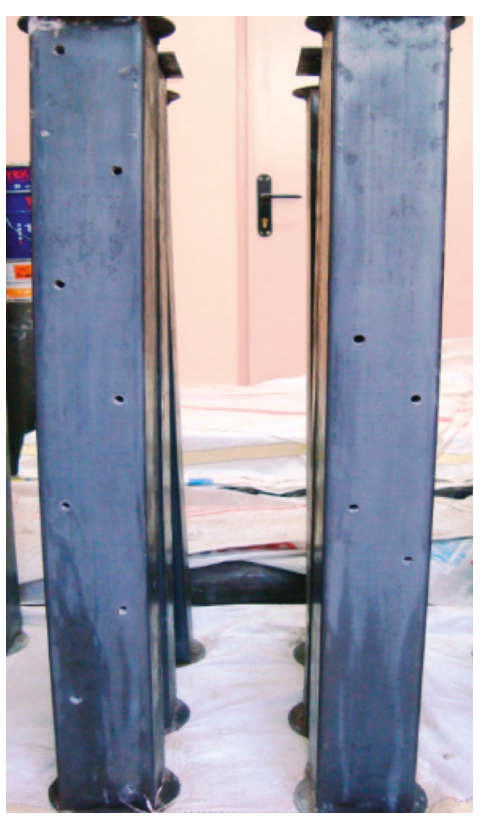

(b)

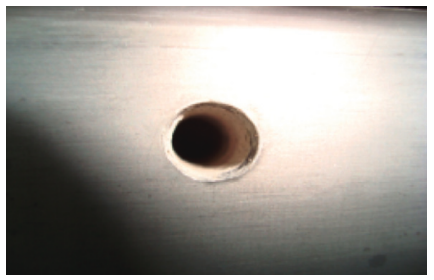

(c)
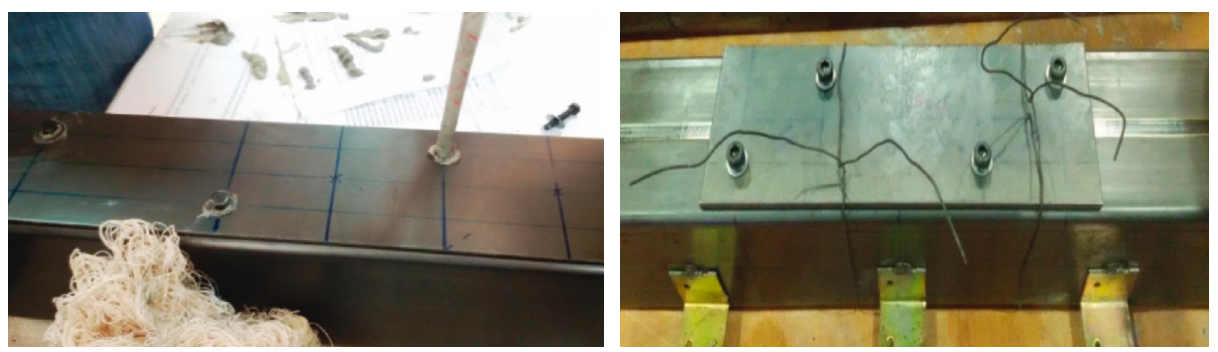

(d)

FIGURE 5: Preparation stages for the retrofitted beams. (a) SCCFST beams. (b) Drilled SCCFST beams. (c) Typically drilled hole. (d) Application of epoxy and installation of bolts through holes.

TABLE 6: Dimensions and details of the beam specimens.

\begin{tabular}{|c|c|c|c|c|}
\hline Group name & Beam designation & $\begin{array}{c}\text { Beam dimensions } \\
H \times B \times t(\mathrm{~mm})\end{array}$ & $\begin{array}{c}\text { Steel plate dimensions } \\
\quad B_{\mathrm{p}} \times t_{\mathrm{p}} \times L_{\mathrm{p}}(\mathrm{mm})\end{array}$ & Details \\
\hline \multirow{6}{*}{ Group A (single bottom plate) } & HB-A & $100 \times 100 \times 3$ & - & Hollow \\
\hline & CB-A & & - & Control \\
\hline & IB-PL-SB & & $94 \times 3 \times 925$ & Intact \\
\hline & IB-FL-SB & & $94 \times 3 \times 300$ & Intact \\
\hline & RB-PL-SB & & $94 \times 3 \times 925$ & Retrofit \\
\hline & RB-FL-SB & & $94 \times 3 \times 300$ & Retrofit \\
\hline \multirow{6}{*}{ Group B (top and bottom plates) } & HB-B & $100 \times 100 \times 3$ & - & Hollow \\
\hline & CB-B & & - & Control \\
\hline & IB-PL-TB & & $94 \times 3 \times 925$ & Intact \\
\hline & IB-FL-TB & & $94 \times 3 \times 300$ & Intact \\
\hline & RB-PL-TB & & $94 \times 3 \times 925$ & Retrofit \\
\hline & RB-FL-TB & & $94 \times 3 \times 300$ & Retrofit \\
\hline \multirow{6}{*}{ Group C (double bottom plates) } & HB-C & $100 \times 100 \times 3$ & - & Hollow \\
\hline & $\mathrm{CB}-\mathrm{C}$ & & - & Control \\
\hline & IB-PL-DB & & $94 \times 3 \times 925$ & Intact \\
\hline & IB-FL-DB & & $94 \times 3 \times 300$ & Intact \\
\hline & RB-PL-DB & & $94 \times 3 \times 925$ & Retrofit \\
\hline & RB-FL-DB & & $94 \times 3 \times 300$ & Retrofit \\
\hline
\end{tabular}

Note: $H, B, t$ : beam depth, width, and thickness; $B_{\mathrm{p}} \times t_{\mathrm{p}} \times L_{\mathrm{p}}$ : steel plate width, thickness, and length. 


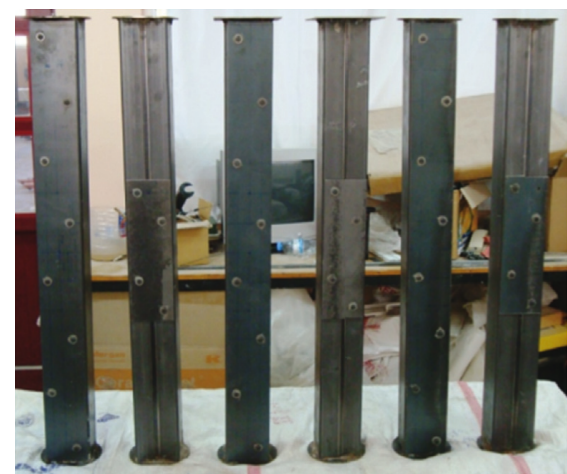

(a)

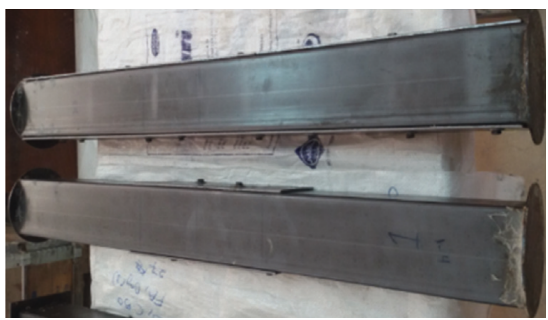

(d)

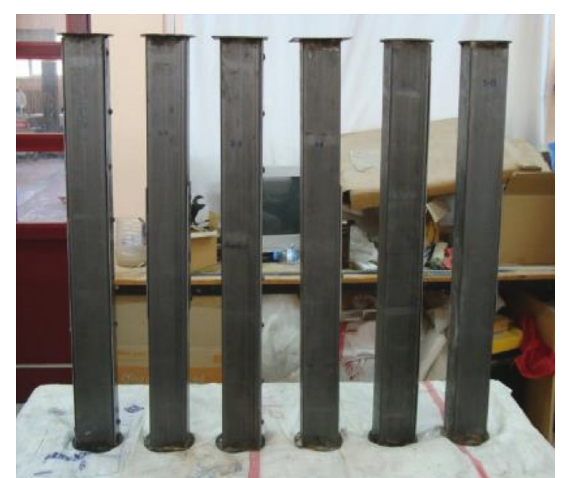

(b)

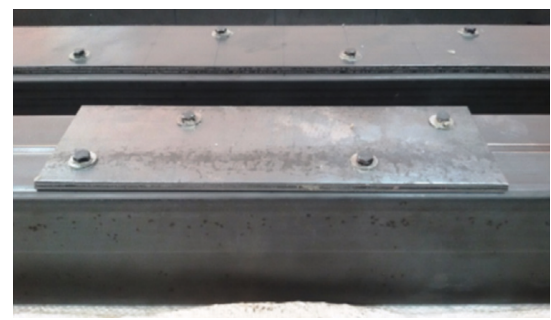

(e)

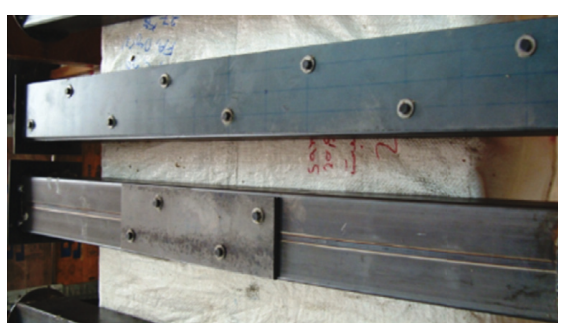

(c)

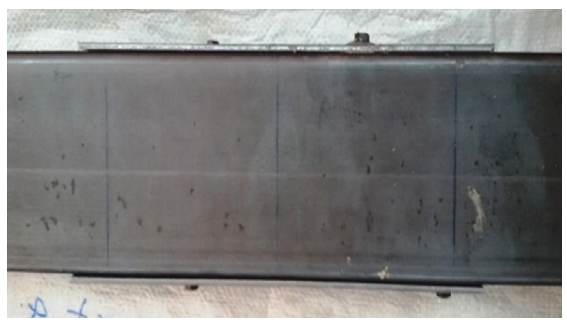

(f)

Figure 6: Retrofitting schemes of SCCFST beams. (a) Bottom flange view. (b) Side view. (c) Groups A and C retrofitting schemes. (d) Group B retrofitting scheme. (e) Double bottom steel plates. (f) Top and bottom steel plates.

connected to only one third (middle third) of the beam length. Figure 6 illustrates the details of the various retrofitting schemes adopted to the SCCFST beam specimens.

The following labelling system was used to designate each beam specimen in Table 6. For instance, HB and CB indicate hollow steel tube and control (unstrengthened) SCCFST beams, respectively. RB-PL-SB and RB-FL-SB represent damaged beams (RB) retrofitted by single bottom (SB) steel plates with partial length (PL) or full length (FL), respectively. Whereas, IB-PL-SB and RB-FL-SB refer to the strengthened intact beams (IB). Similarly, SCCFST beams in groups B and $\mathrm{C}$ have the same designations of the above beams, except the symbols (TB) in group $B$ and (DB) in group $C$ which refer to retrofitting with top and bottom (TB) steel plates and double bottom steel (DB) plates, respectively.

3.4. Test Procedure. All the beam specimens were tested under pure bending moment up to failure. All beam specimens had a span length of $950 \mathrm{~mm}$ (an effective span of $750 \mathrm{~mm}$ ) and were placed in a simply supported condition as shown in Figure 7. The $500 \mathrm{KN}$ capacity testing machine was used to conduct the test. The beams were tested under the four-point loading method providing a constant bending zone of $250 \mathrm{~mm}$. The force was applied using a displacement control method with a loading rate of $1 \mathrm{~mm} / \mathrm{min}$. The implementation of displacement control method allowed the experiments to be continued into the post-peak stage and enabled better control when recording the postultimate behaviour [37]. Deflections along the beam span were measured by three linear variable displacement transducers (LVDTs). One was placed at the midspan of the specimen;

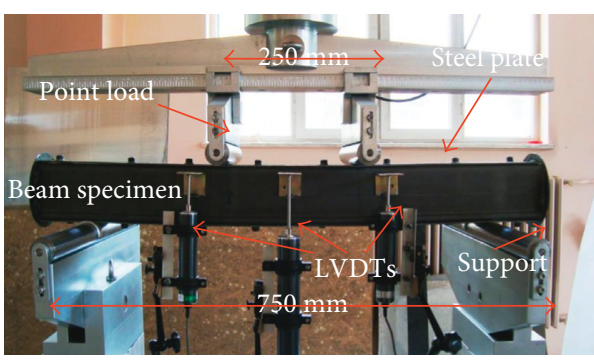

FIgURE 7: Beam test setup.

the other two were placed under concentrated loads with the shifting of $50 \mathrm{~mm}$ from the left and right of the concentrated load positions as shown in Figure 7. The above testing procedure was applied directly to the hollow, control, and intact SCCFST beams. However, for the retrofitted SCCFST beams, a preloading stage was implemented to simulate the damage condition. To achieve this goal, SCCFST beams were preloaded before retrofitting. The preloading stage was done using the same loading setup as explained above. In the beginning, the beams were loaded until reaching a moment capacity of $90 \%$ of the ultimate moment capacity recorded for the corresponding control beam.

\section{Test Results and Discussion}

4.1. Failure Modes. All the tested composite beam specimens reached their ultimate moment capacity with no lateral movement signs of the cross section or any other instability form. The typical failure modes of all the SCCFST beams are shown in Figure 8. 

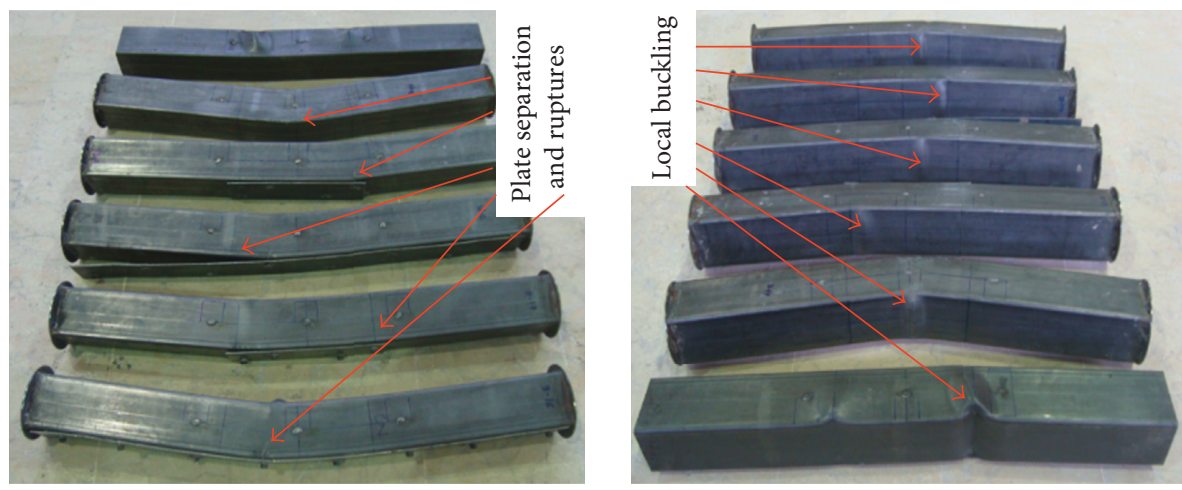

(a)
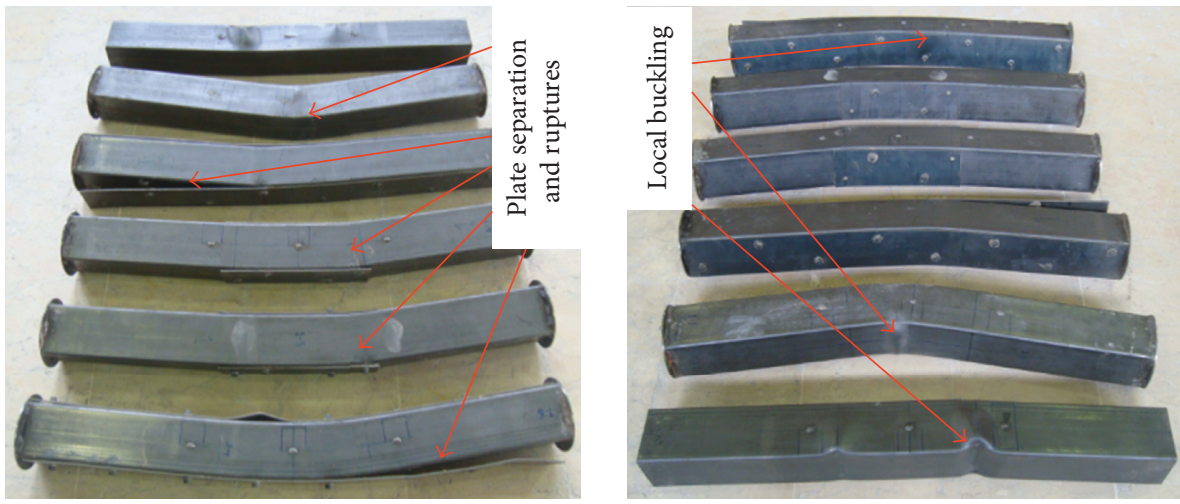

(b)
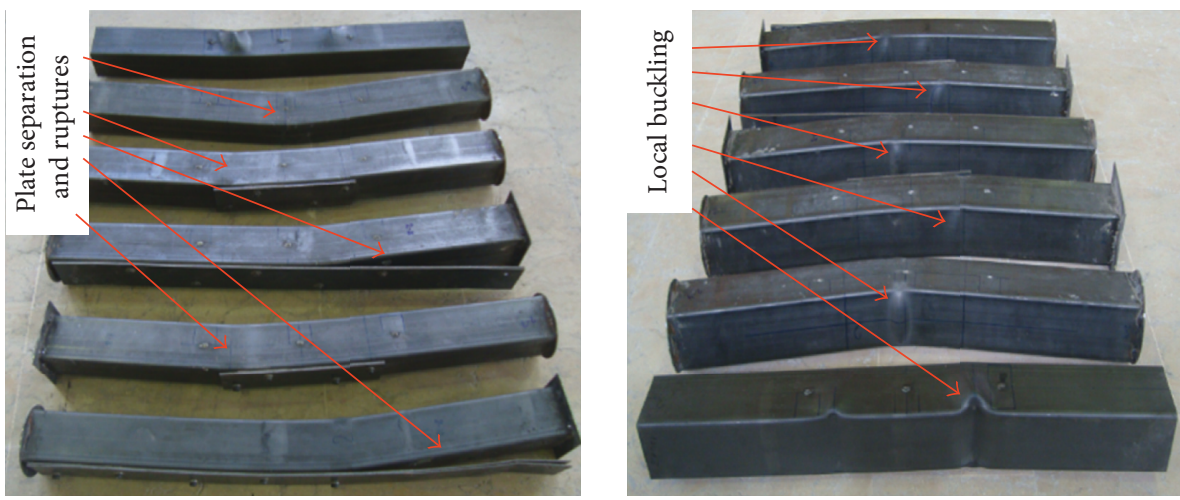

(c)

Figure 8: Failure modes of tested beams (general). (a) Group A retrofitting scheme (single bottom plate: SB). (b) Group B retrofitting scheme (top and bottom plates: TB). (c) Group C retrofitting scheme (double bottom plates: DB).

The hollow steel tube beams in all groups failed by the inward local buckling mode under the two loading points at the top flange. On the other hand, SCCFST control beams failed by the outward local buckling mode of the steel tube at the top compression flange with a single outward local buckling at the midspan section within the constant bending moment zone. It can be expected that the concrete at the local buckling locations was crushed. Finally, the control beams failed by initiation of rupture at the bottom tensile steel flange at the same location of the observed local buckling as shown in Figure 9(a). It was obvious that the concrete core at the rupture zone was cracked. The difference in failure modes between SSCFST beams and the hollow beams indicated that the SCCFST core was able to change the failure mode of the hollow steel beam from inward to outward local buckling at a greater flexural strength and deformation capacity.

Regarding beams of group A (single bottom steel plate retrofitting scheme), the typical failure mode of all the intact and retrofitted beams with different retrofitting lengths (beams retrofitted partially or entirely along their length) was outward local buckling of the top compression steel flange as shown in Figure 8(a). Similar to the control beams, outward local buckling was observed either close to the midspan section or near the locations of the applied loads within the constant bending zone. In addition to the local 

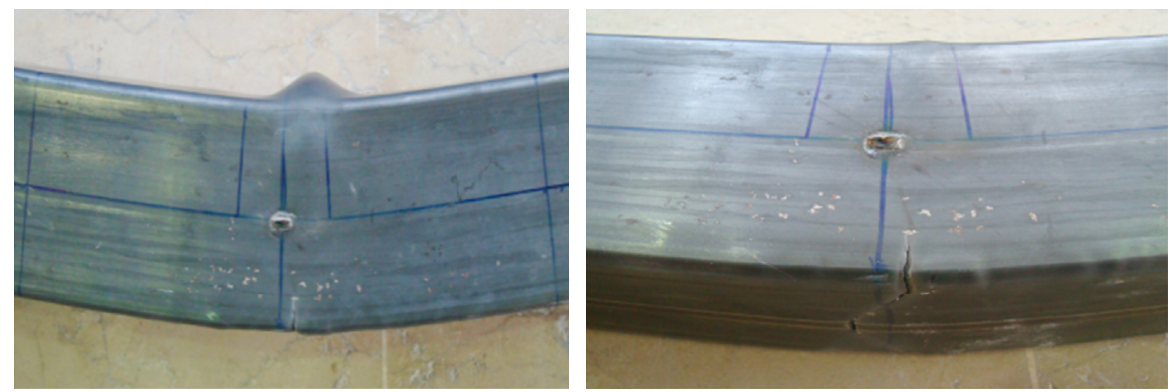

(a)

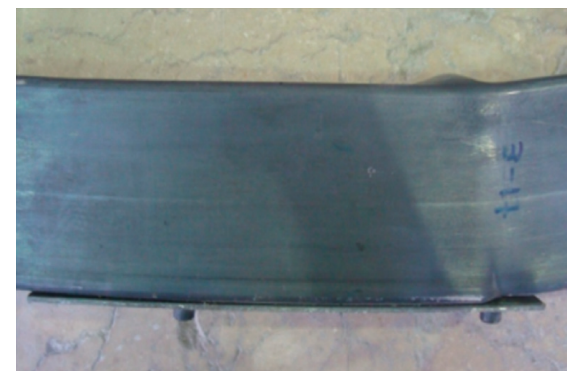

(b)

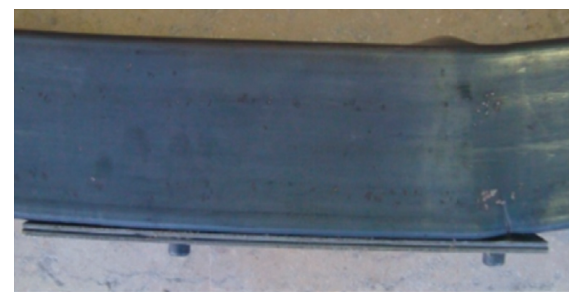

(d)

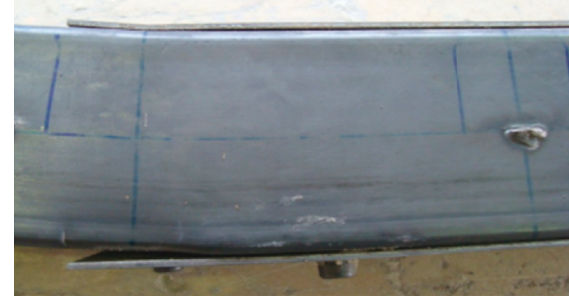

(f)

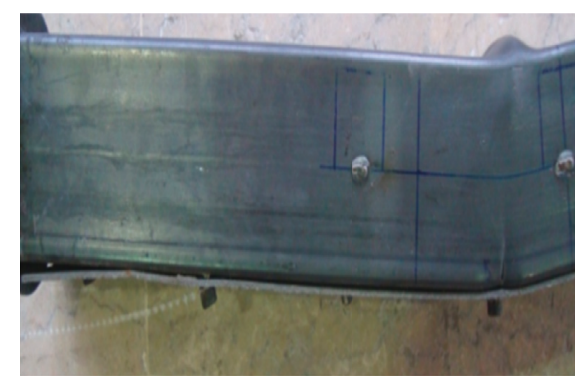

(c)

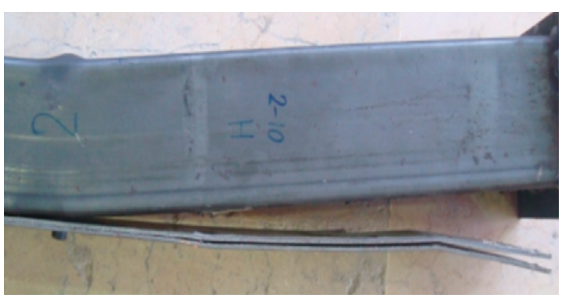

(e)

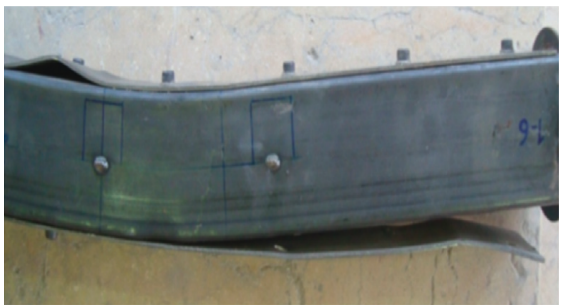

$(\mathrm{g})$

FIGURE 9: Failure modes of control and retrofitted beams. (a) Typical local buckling and rupture of control beam. (b) RB-PL-SB. (c) RB-FLSB. (d) RB-PL-DB. (e) RB-FL-DB. (f) RB-PL-TB. (g) RB-PL-TB.

buckling mode, the intact and retrofitted beams which partially strengthened along their length (IB-PL-SB and RBPL-SB) revealed a rupture failure mode of the bottom tension flange at the location of the fixing bolts as shown in Figures 8(a) and 9(b). On the other hand, intact and retrofitted beams which fully strengthened along their length (IB-FL-SB and RB-FL-SB) revealed a different failure trend. Beams IB-FL-SB and RB-FL-SB underwent ruptures of some of their anchoring bolts within the beam shear span. This failure mode resulted in delamination and separation of the attached retrofitting single plate from the beam bottom flange on one side due to the successive bolt rupture. Finally, the local buckling, bolt rupture, and steel plate separation developed the rupture failure of the tension bottom flange at the location of one of the bolts which are close to the boundary of the constant bending zone, as shown in Figures 8 (a) and 9(c).

Relating to beams of group C (double bottom steel plate retrofitting scheme), Figure 8(c) showed that all beams failed with the typical local buckling mode of the top compression flange in a comparable mode to those recorded in the control beams and beams of group A, as shown in Figure 8(c). Furthermore, concerning the failure modes of the bolted double bottom steel plates and the bottom tension flange of the tested beams, all beams in this group (C) showed similar failure mechanism as that stated previously for their counterparts in group A, as shown in Figures 8(c), 9(d), and $9(\mathrm{e})$. Hence, it can be indicated that beams of groups $\mathrm{A}$ and $\mathrm{C}$ 


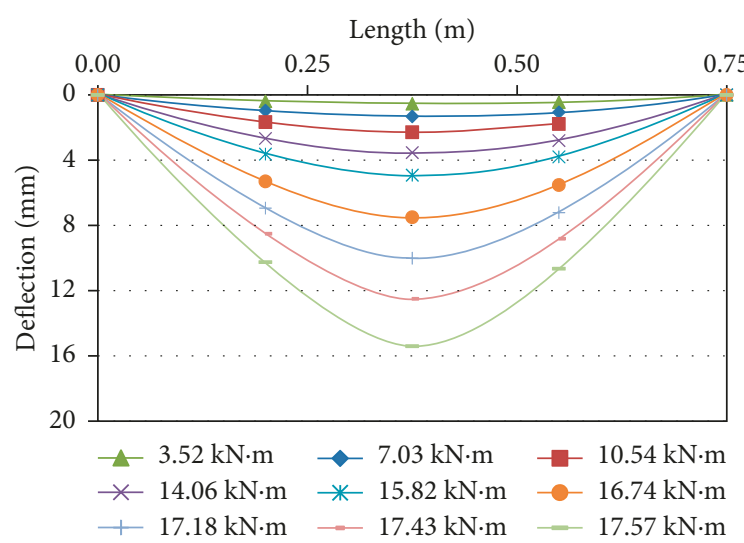

(a)

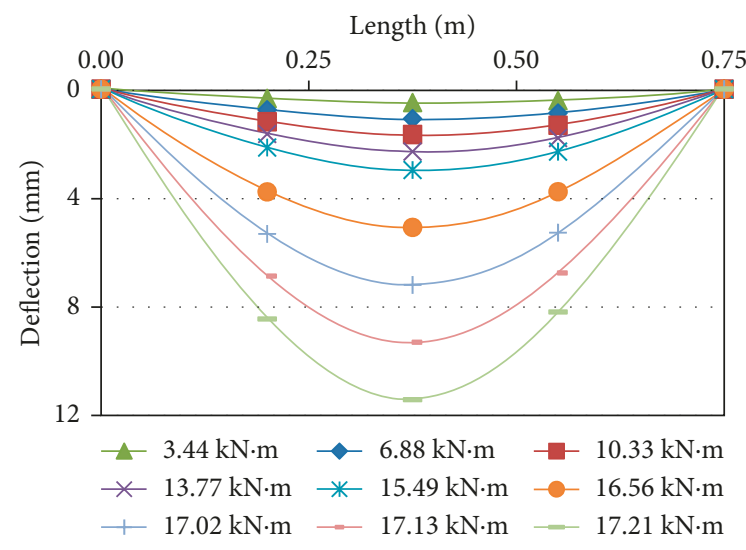

(c)

Figure 10: Deflection curves along different loading stages. (a)

had almost identical failure modes regardless the difference of retrofitting scheme (single or double bottom steel plates).

Finally, considering beams of group B (top and bottom steel plate retrofitting scheme), beams of this group revealed a characterized different failure mode compared to their counterparts in other groups. The major difference was that no local buckling was recognized at the top steel flange of all the beams, as shown in Figure 8(b). This may be attributed to the existence of the top retrofitting steel plate. Furthermore, another interesting observation was recorded. An upward local buckling appeared at the top retrofitting steel plate of the beam (RB-FL-TB) which was retrofitted along its full length, as shown in Figure 9(f). This phenomenon was unique in this beam specimen. Nevertheless, regarding the tension failure modes, all beams in this group (B) were exhibited similar failure mechanism as that recorded for their counterparts in the other groups, as depicted in Figures 8(b), 9(f), and 9(g). Finally, it can be concluded that the failure modes of beams in group B were to some extent featured from those noticed in other groups. The adoption of anchored top steel plates, fastened to the top flange of the SCCFST beam, was an effective retrofitting technique. This technique was able to change the predominated local buckling mode of CFST beams and hence lead to relatively increase the flexural strength of retrofitted beams compared to the other retrofitting schemes (group A and C).

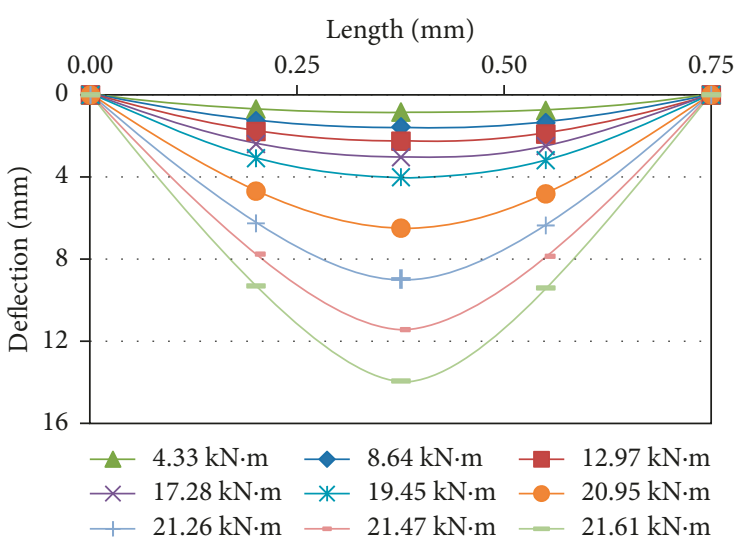

(b)

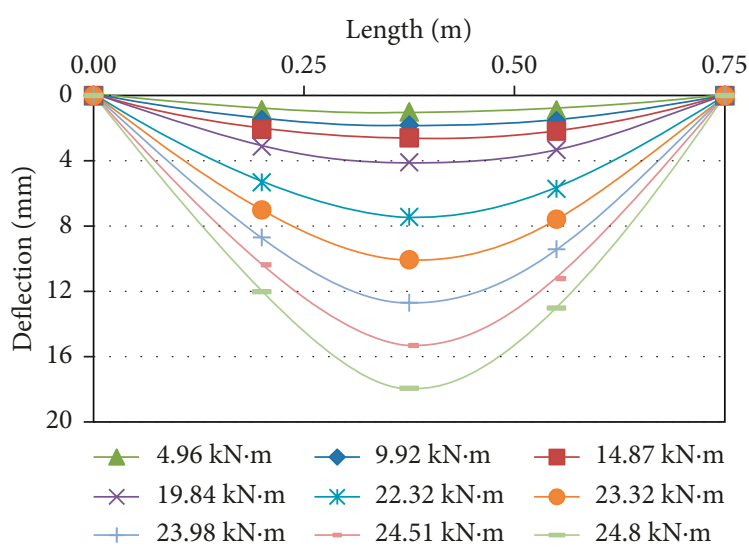

(d)

a) CB (control beam). (b) RB-FL-SB. (c) RB-PL-DB. (d) RB-FL-TB.

Figure 10 shows the deflection curves along the length of typical control beam and typical retrofitted beams for each group versus different bending moment levels. From these figures, it was detected that the curves are symmetrical, and the deflection curves take the shape of half sine wave curves.

4.2. Moment $(M)$ versus Midspan Deflection $\left(D_{\mathrm{m}}\right)$ Curves. The moment $(M)$ versus midspan deflection $\left(D_{\mathrm{m}}\right)$ curves of all the tested beams are depicted in Figures 11(a)-11(c) for the three retrofitting scheme groups $\mathrm{A}, \mathrm{B}$, and $\mathrm{C}$, respectively. Also, Figure 12 represents the typical moment versus midspan deflection curves of the preloaded beams compared to the control beams.

All the tested control SCCFST beams (CB-A, CB-B, and CB-C) exhibited an elastic behaviour during the initial loading stage, followed by inelastic behaviour with a gradual reduction in flexural stiffness until reaching the ultimate moment capacity. Then, the control beams showed a plastic behaviour with large deformation capacity and associated with almost constant flexural strength up to the initiation of bottom steel rupture. The reduction in moment capacity at the failure point was less than $4 \%$ of the ultimate moment capacity. This behaviour reflects the superior ductile behaviour of the SCCFST beams. 


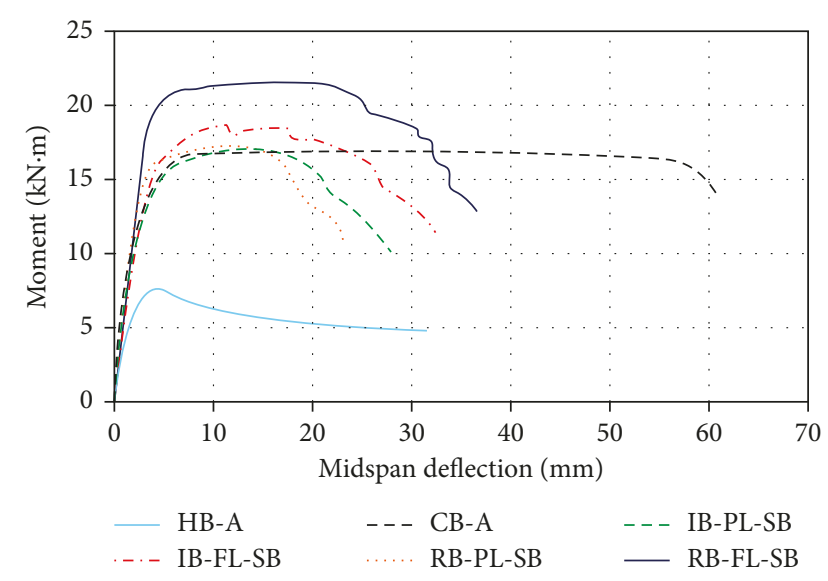

(a)

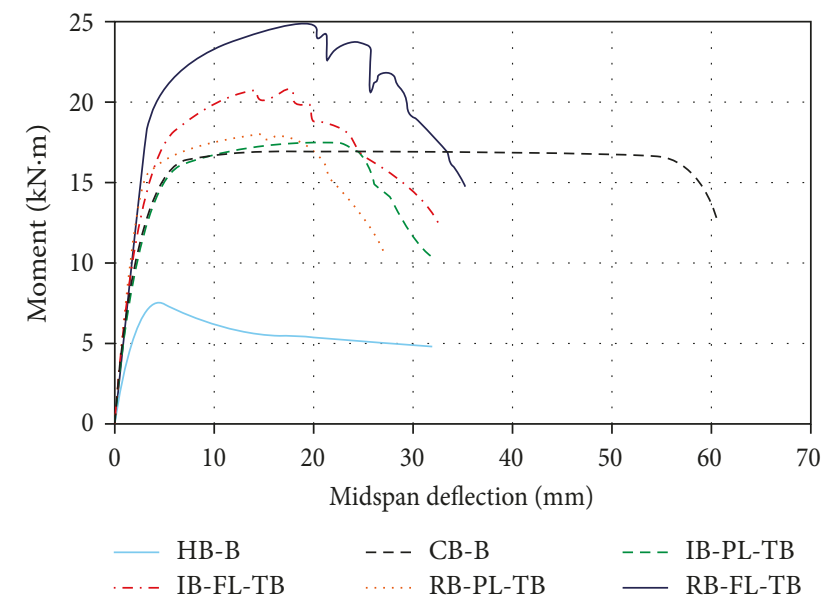

(b)

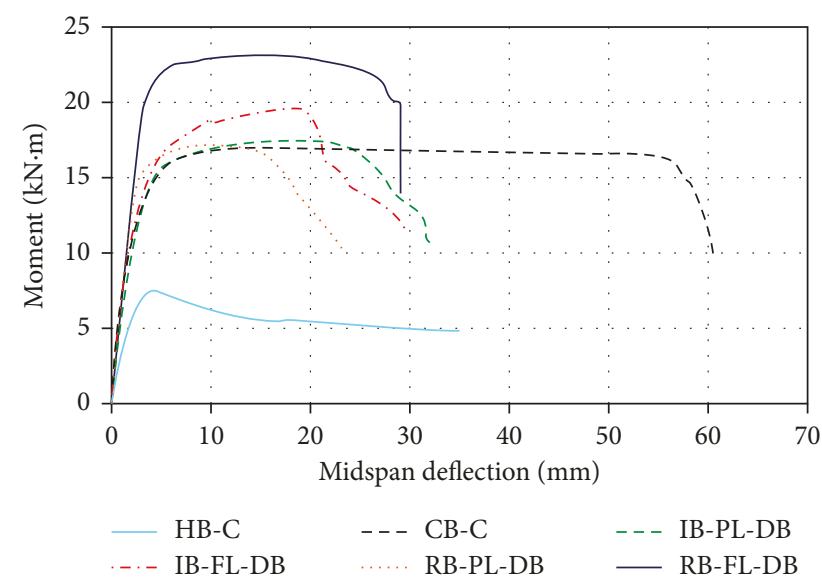

(c)

Figure 11: Moment versus midspan deflection curves. (a) Beams of group A. (b) Beams of group B. (c) Beams of group C.

Figure 12 indicates that the preloaded beams followed exactly the same path of the control beams up to their predetermined loading stage. This response reflected the ability to conduct a healthy comparison between the retrofitted beams and their counterpart control beams. The preloaded beams were loaded up to an average bending

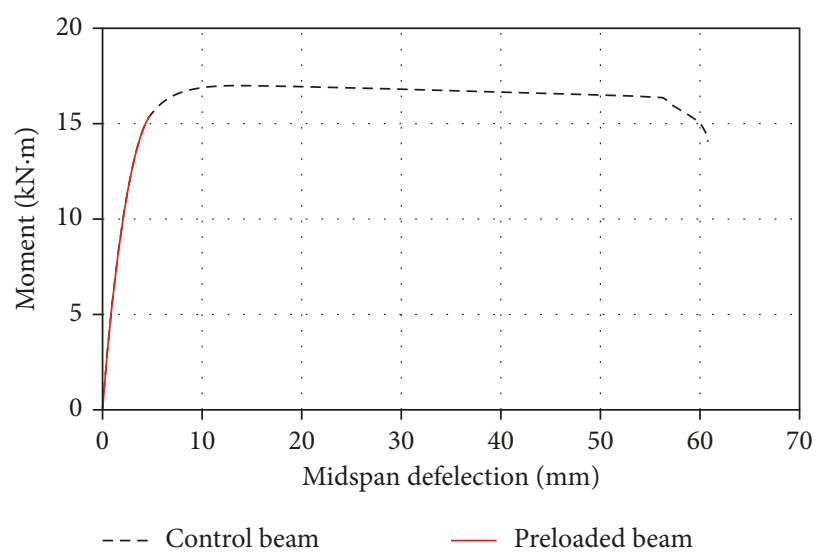

FIgURE 12: Typical moment versus midspan deflection curve of preloaded beams.

moment of $15.322 \mathrm{kN} \cdot \mathrm{m}$ which represents about $90 \%$ of the average ultimate moment achieved by the control beam.

In general, all the intact and retrofitted SCCFST beams behaved in an elastic behaviour followed by an inelastic response with a gradual reduction in flexural stiffness up to the ultimate moment capacity. This performance is close to that showed by the control beams. However, some differences in behaviour were detected from the moment versus midspan deflection curves, as will be described in the next sections.

All the intact SCCFST beams followed the similar elastic and inelastic behaviour of the control SCCFST beams with almost similar flexural stiffness. However, the major difference was in the plastic behaviour. The intact specimens showed limited plastic zone compared to the control beams. This may attribute to the reduction in the cross-sectional area of the bottom tensile flanges of the beams and strengthen steel plates and some deficiency that may occur in the concrete core due to the predrilled holes. Intact beams (IB-PL-SB, IB-PL-TB, and IB-PL-DB) which are partially strengthened showed similar flexural strength and stiffness compared to that obtained for the control beams. However, beams (IB-FL-SB, IB-FL-TB, and IB-FL-DB) which are fully strengthened (steel plates applied over the full beam length) showed some greater flexural strength compared to both control beams and partially strengthened beams.

Generally, all the retrofitted SCCFST beams exhibited similar elastic and inelastic response to those of the control SCCFST beams. However, the retrofitted beams revealed greater flexural stiffness. The partial retrofitted beams (RBPL-SB, RB-PL-TB, and RB-PL-DB) showed close ultimate flexural strength to those obtained by the control beams and their counterpart intact beams (IB-PL-SB, IB-PL-TB, and IB-PL-DB). However, these beams also had a limited plastic zone and hence lower ductility compared to the control beams, similar to their intact counterpart beams. The fully retrofitted beams (RB-PL-SB, RB-PL-TB, and RB-PL$\mathrm{DB})$ exhibited larger flexural strength and stiffness compared to all other tested beams in this experimental work. This potential enhancement in flexural strength and stiffness was more booming in retrofitted beams that belong to 
TABLE 7: Ultimate moments and percentage of increase in moment capacity.

\begin{tabular}{|c|c|c|c|}
\hline Group name & $\begin{array}{l}\text { Designation } \\
\text { of beams }\end{array}$ & $\begin{array}{l}\text { Moment capacity } \\
(\mathrm{kN} \cdot \mathrm{m})\end{array}$ & $\begin{array}{c}\text { \% increase in moment capacity } \\
\text { compared to } \mathrm{CB}(\mathrm{kN} \cdot \mathrm{m})\end{array}$ \\
\hline \multirow{6}{*}{ Group A (single bottom plate) } & HB-A & 7.62 & - \\
\hline & CB-A & 17.04 & - \\
\hline & IB-PL-SB & 16.99 & 0.00 \\
\hline & IB-FL-SB & 18.69 & 9.70 \\
\hline & RB-PL-SB & 17.20 & 0.92 \\
\hline & RB-FL-SB & 21.61 & 26.80 \\
\hline \multirow{6}{*}{ Group B (top and bottom plates) } & HB-B & 7.56 & - \\
\hline & CB-B & 17.04 & - \\
\hline & IB-PL-TB & 17.57 & 3.14 \\
\hline & IB-FL-TB & 20.84 & 22.29 \\
\hline & RB-PL-TB & 17.92 & 5.21 \\
\hline & RB-FL-TB & 24.80 & 45.55 \\
\hline \multirow{6}{*}{ Group C (double bottom plates) } & $\mathrm{HB}-\mathrm{C}$ & 7.51 & - \\
\hline & $\mathrm{CB}-\mathrm{C}$ & 17.04 & - \\
\hline & IB-PL-DB & 17.47 & 2.54 \\
\hline & IB-FL-DB & 19.60 & 15.03 \\
\hline & RB-PL-DB & 17.21 & 1.00 \\
\hline & RB-FL-DB & 23.13 & 35.72 \\
\hline
\end{tabular}

the strengthening scheme of group B (RB-FL-TB beam). Furthermore, the fully retrofitted beams (RB-PL-SB, RB-PL-TB, and RB-PL-DB) behaved in a more ductile mode compared to all other retrofitted and intact beams. However, the ductility of these beams was still lower than those obtained for the control beams. Finally, it can be concluded that all the retrofitted beams were able to restore and even to develop enhanced behaviour in terms of flexural strength and stiffness compared to their original undamaged condition.

4.3. Moment Capacities. The ultimate experimental bending moments $\left(M_{\mathrm{u}}\right)$ for all beam specimens in all groups and percentage of increase in moment capacity of the retrofitted beams compared to the control beams are tabulated in Table 7 and depicted in Figure 13.

For group A beams (Figure 13(a)), the percentage increase in the ultimate moment of intact SCCFST beams ranged from about $0 \%$ for beam IB-PL-SB to $9.70 \%$ for beam IB-FL-SB. On the other hand, retrofitted beams achieved a percentage increment in ultimate flexural strength ranged from $0.92 \%$ for beam RB-PL-SB to $26.80 \%$ for beam RB-FL-SB compared to the control beam. It is clear that the maximum advantage of retrofitting the intact SCCFST beams was achieved by using steel plates along the full beam length. However, a slight increase in the ultimate moment was obtained from beams retrofitted with steel plates along the partial beam length. This may attribute to the fact that steel plates with full length covered the full span of intact beams and hence increase both the moment capacity and stiffness. While, for beams with a partially strengthened span, the steel plates were attached only to the pure bending zone and it was not extended to the shear span.

For group B beams (Figure 13(b)), the percentage enhancement in the ultimate moment due to the strengthening of the SCCFST intact beams was varied from $3.14 \%$ for beam IB-PL-TB to $22.29 \%$ for beam IB-FL-TB. Regarding the retrofitted SCCFST beams, the percentage improvement in the ultimate moment capacity due to the retrofitting of the SCCFST damaged (preloaded) beams was varied from $5.21 \%$ for beam RB-PL-TB to $45.55 \%$ for beam RB-FL-TB. Similar to group A, it showed that the maximum benefit of upgrading was obtained by retrofitting the beams along their full length compared to those retrofitted along their partial length. It is worth to note that, that intact and retrofitted beams in this group (group B) attained the highest ultimate moment capacity compared to the beams in other groups (groups A and C) as shown in Figure 13(d). Therefore, it can be stated that the best enhancement in ultimate flexural strength was gained due to the adopting of group B retrofitting technique (top and bottom steel plates).

For group C beams (Figure 13(c)), the percentage increase in the ultimate moment due to the strengthening of SCCFST intact beams ranged from $2.54 \%$ for beam IB-PLDB to $21.59 \%$ for beam IB-FL-DB. However, the percentage increment in the ultimate moment due to the retrofitting of SCCFST damaged beams ranged from $1.00 \%$ for beam RBPL-DB to $35.72 \%$ for beam IB-FL-DB. Similar to groups A and $B$, it is evident that the maximum avail of retrofitting of SCCFST beam was achieved by adopting full retrofitting scheme rather than partial retrofitting schemes. Furthermore, the retrofitting scheme used in this group (double bottom plates) provides a moderate improvement in ultimate flexural strength compared to the other retrofitting schemes adopted in groups A (single bottom plate) and B (top and bottom plates).

Finally, it can be indicated that all the adopted retrofitting schemes were effective in restoring the flexural strength of the damaged beams and even enhance the ultimate flexural strength, especially for beams retrofitted along their full span length. Moreover, among the 


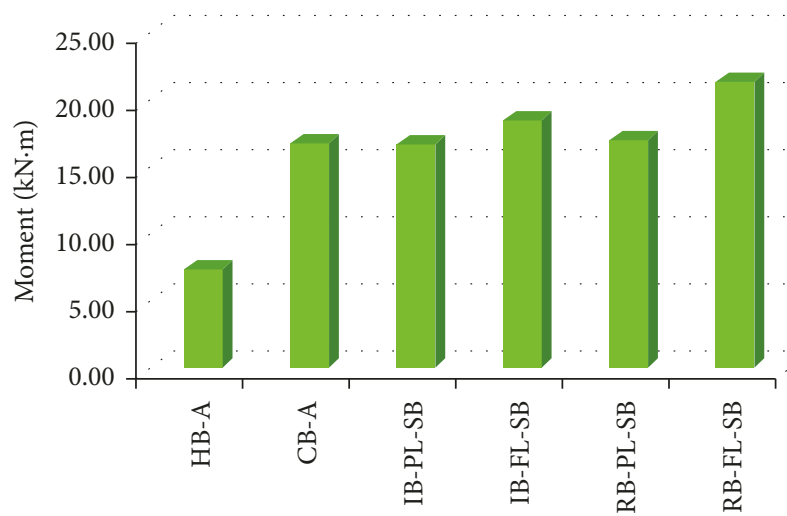

(a)

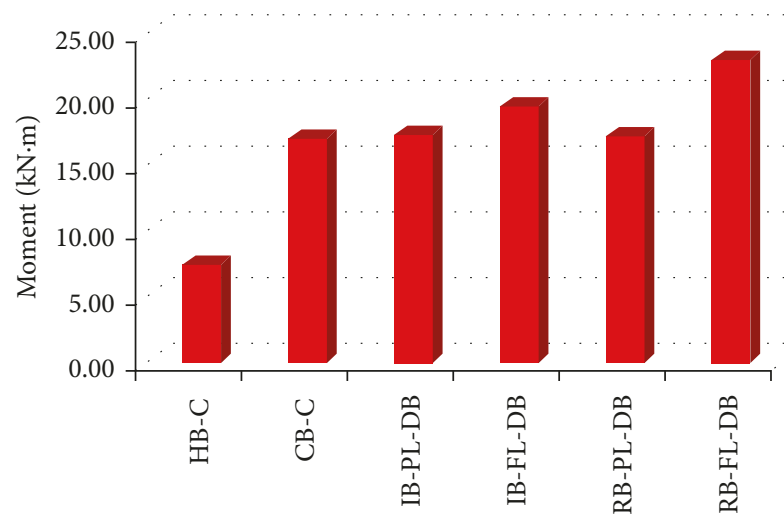

(c)

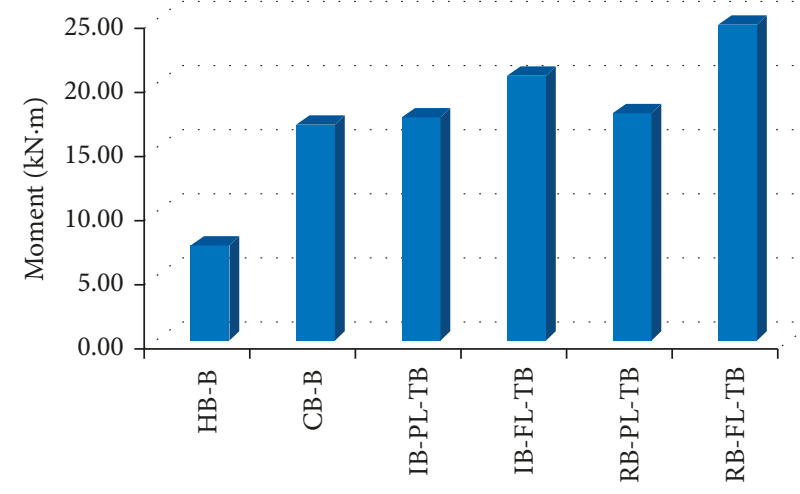

(b)

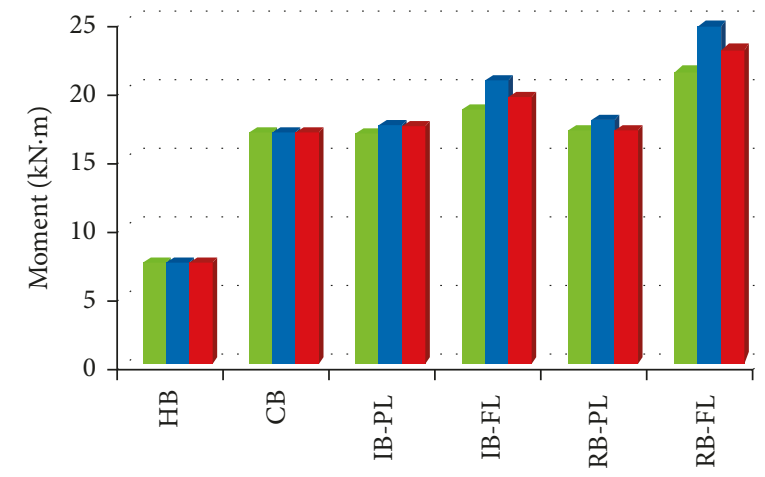

- Group A
- Group B
- Group C

Figure 13: Ultimate moment capacity. (a) Group A beams. (b) Group B beams. (c) Group C beams. (d) Comparison.

three different upgrading schemes, it was found that the retrofitting method of damaged beams using top and bottom steel plates was the most effective method.

4.4. Ductility Capacities. Ductile performance of beams implies the ability to absorb as much energy as possible before failure. The ductility of the tested beams was evaluated by the modulus of toughness (MOT), which represents the entire area under the load-deflection curves. Furthermore, the relative ductility index (RDI) of the tested beams was calculated which represents the ratio of ductility achieved by the retrofitted and intact beams to the ductility of the control beams. The results of the relative ductility index and modulus of toughness are listed in Table 8 and illustrated in Figure 14.

For group A beams, the RDI of intact beams ranged from 0.41 for beam IB-PL-SB to 0.53 for beam IB-FL-SB which referred to about 53\% (average value) reduction in ductility compared to the control beam. However, for the retrofitted beams, the RDI ranged from 0.35 for beam RB-PL-SB to 0.70 for beam IB-FL-SB which indicated that the retrofitted beams were able to restore about $35 \%$ to $70 \%$ of the original ductility of the control beam.
For group B beams, the RDI of intact beams varied from 0.49 for beam IB-PL-SB to 0.57 for beam IB-FL-SB which referred to about $47 \%$ (average value) reduction in ductility compared to the control beam. On the other hand, for the retrofitted beams, the RDI ranged from 0.43 for beam RBPL-TB to 0.75 for beam IB-FL-TB which implied that the retrofitted beams were able to recover about $43 \%$ to $75 \%$ of the original ductility of the control beam. It is worth noting that the retrofitted beams in this group developed the highest ductility compared to their counterparts in other groups. This pointed that, the retrofitting scheme adopting in this group (top and bottom steel plates) demonstrated the most efficient retrofitting technique.

For group $\mathrm{C}$ beams, the RDI of intact beams was about 0.50 (average) which refereed to about 50\% lower ductility compared to the control beam. However, regarding the retrofitted beams, the RDI ranged from 0.35 for beam RBPL-DB to 0.63 for beam RB-FL-DB which indicated that the retrofitted beams were capable of getting back about $35 \%$ to $63 \%$ of the original ductility of the control beam. However, retrofitted beams of this group attained the lowest ductility relative to beams in other groups.

Finally, similar to the moment capacities, it is obvious that the full retrofitting scheme is much efficient than the partial 
TABLE 8: Modulus of toughness and relative ductility.

\begin{tabular}{lccc}
\hline Group name & Designation of beams & Modulus of toughness (kN.mm) & Relative ductility index (RDI) \\
\hline & CB-A & 7841.9 & 1.00 \\
Group A (single bottom plate) & IB-PL-SB & 3201.1 & 0.41 \\
& IB-FL-SB & 4120.9 & 0.53 \\
& RB-PL-SB & 2776.5 & 0.35 \\
& RB-FL-SB & 5511.5 & 0.70 \\
\hline & CB-B & 7832.3 & 1.00 \\
Group B (top and bottom plates) & IB-PL-TB & 3824.8 & 0.49 \\
& IB-FL-TB & 4470.1 & 0.57 \\
& RB-PL-TB & 3338.2 & 0.43 \\
& RB-FL-TB & 5864.4 & 0.75 \\
Group C (double bottom plates) & CB-C & 7.00 \\
& IB-PL-DB & 3980.2 & 0.51 \\
& IB-FL-DB & 3801.3 & 0.49 \\
& RB-PL-DB & 2742.1 & 0.35 \\
\end{tabular}

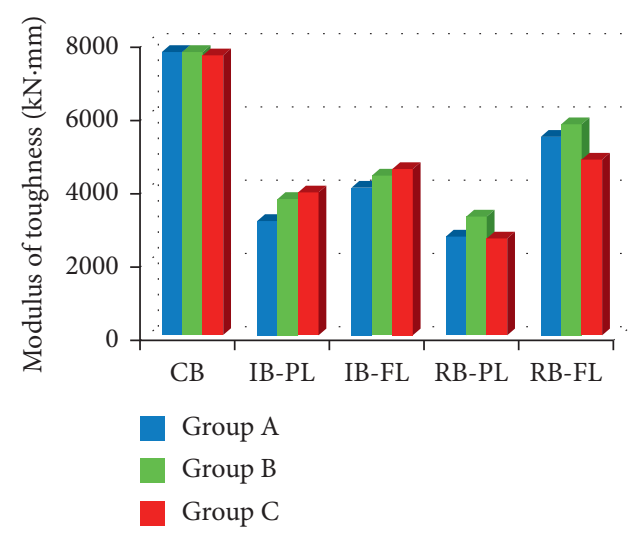

(a)

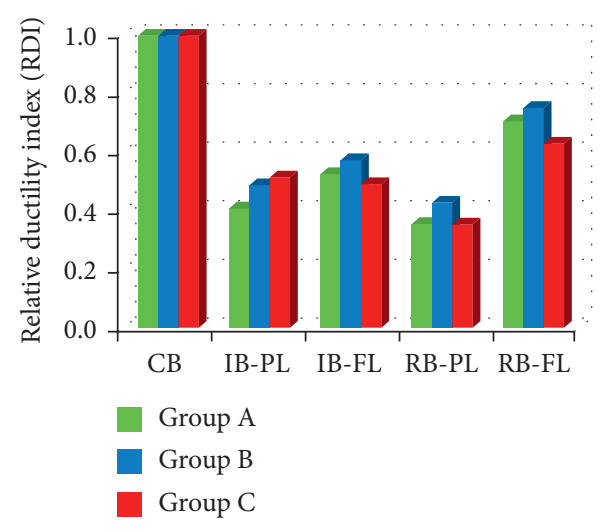

(b)

FIgURE 14: Ductility capacities. (a) Modulus of toughness. (b) Relative ductility index.

retrofitting scheme regarding the improvement in ductility and energy absorption capacity of the retrofitted beams.

\section{Theoretical Model for the Ultimate Moment Capacity}

The American specification AISC 360-10 [38] provides a theoretical model for predicting the ultimate moment capacity of normal concrete-filled steel tube (NCFST) members based on the plastic stress distribution method. Furthermore, Lai et al. [3] reported more details about the calculations of the moment capacities for the NCFST members based on the original model described by AISC 360-10. However, the main limitation of this model is that it was developed to predict the moment capacity of NCFST beams without external retrofitting steel plates. That is to say, the AISC 360-10 model did not take into consideration the effect of the external retrofitting steel plates. It is expected that the existence of external steel plates will increase the ultimate moment capacity of the CFST beams. However, this increase cannot be accounted for by using the AISC 360-10 model. So that, the adoption of the AISC 360-10 model will result in a considerable underestimation (conservative) in predicting the ultimate flexural strength of the retrofitted SCCFST beams using external steel plates.

In this study, a new theoretical model based on the AISC 360-10 [38] model and Lai et al. [3] calculation equations were developed. The new model is developed in such a way to take into consideration the effect of external retrofitting steel plates on the prediction of the ultimate moment capacity of SCCFST beams. The developed model utilizes the plastic stress distribution method as described in the AISC 360-10 specification to compute the plastic moment $\left(M_{\mathrm{p}}\right)$ capacity of the beam cross section as shown in Figure 15. This plastic moment strength represents the nominal flexural $\left(M_{n}\right)$ capacity of retrofitted rectangular SCCFST beams with compact sections using external steel plates. The plastic stress method assumes that the steel and concrete materials have a rigid plastic behaviour. This approach considers that the steel stress in tension and compression is equal to the yield stress $\left(f_{\mathrm{y}}\right)$, while the concrete stress is equal to $0.85 f_{\mathrm{c}}^{\prime}$ in compression and equal to zero in tension. In this model, the effect of retrofitted steel plates was taken into consideration by considering that the external steel plates at the compression and tension sides can reach their yielding stress $\left(f_{\mathrm{y}}\right)$ in a similar way to that assumed for the steel section. 


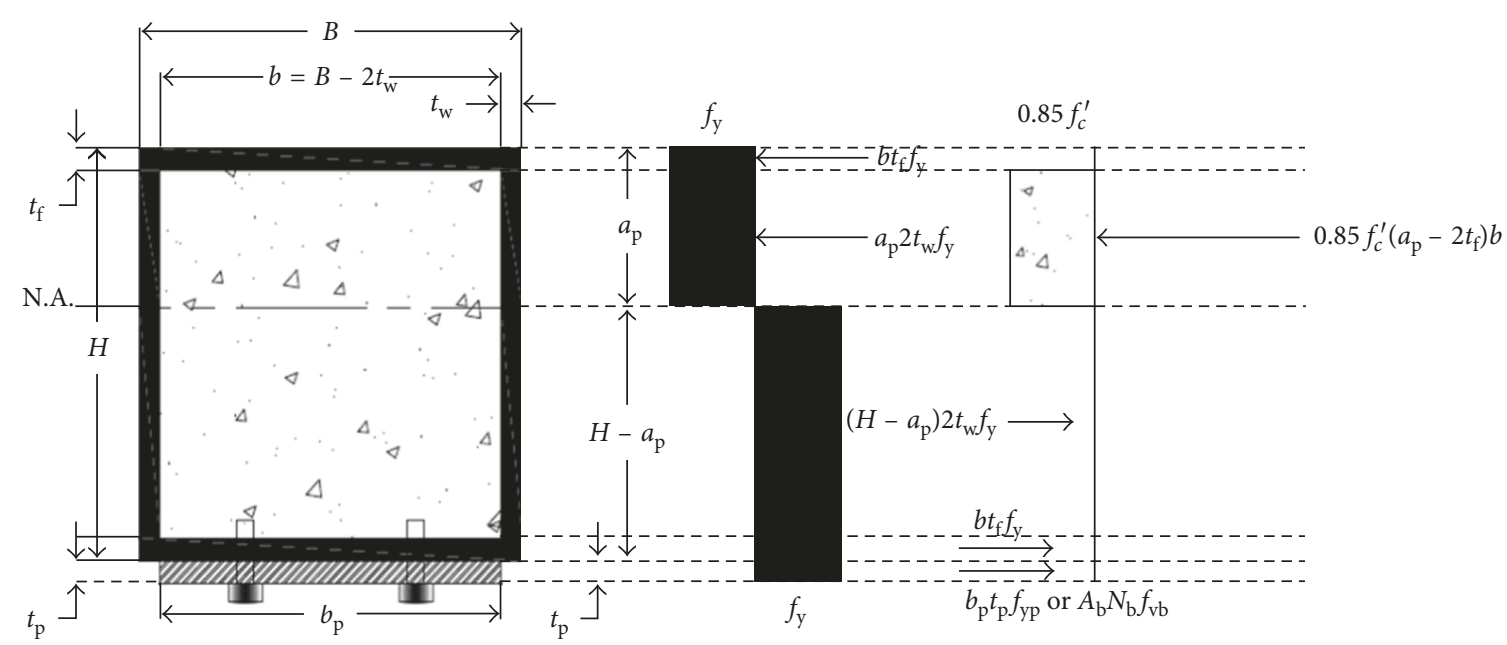

(a)

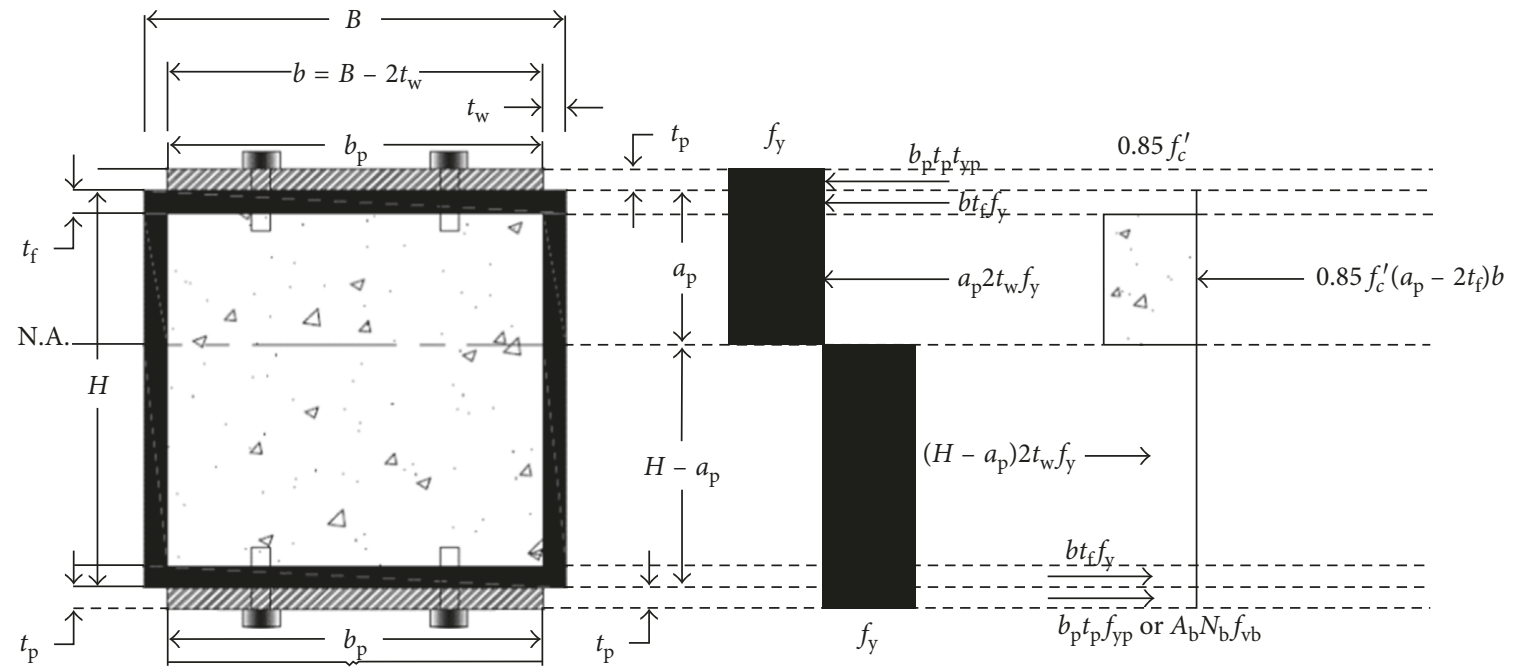

(b)

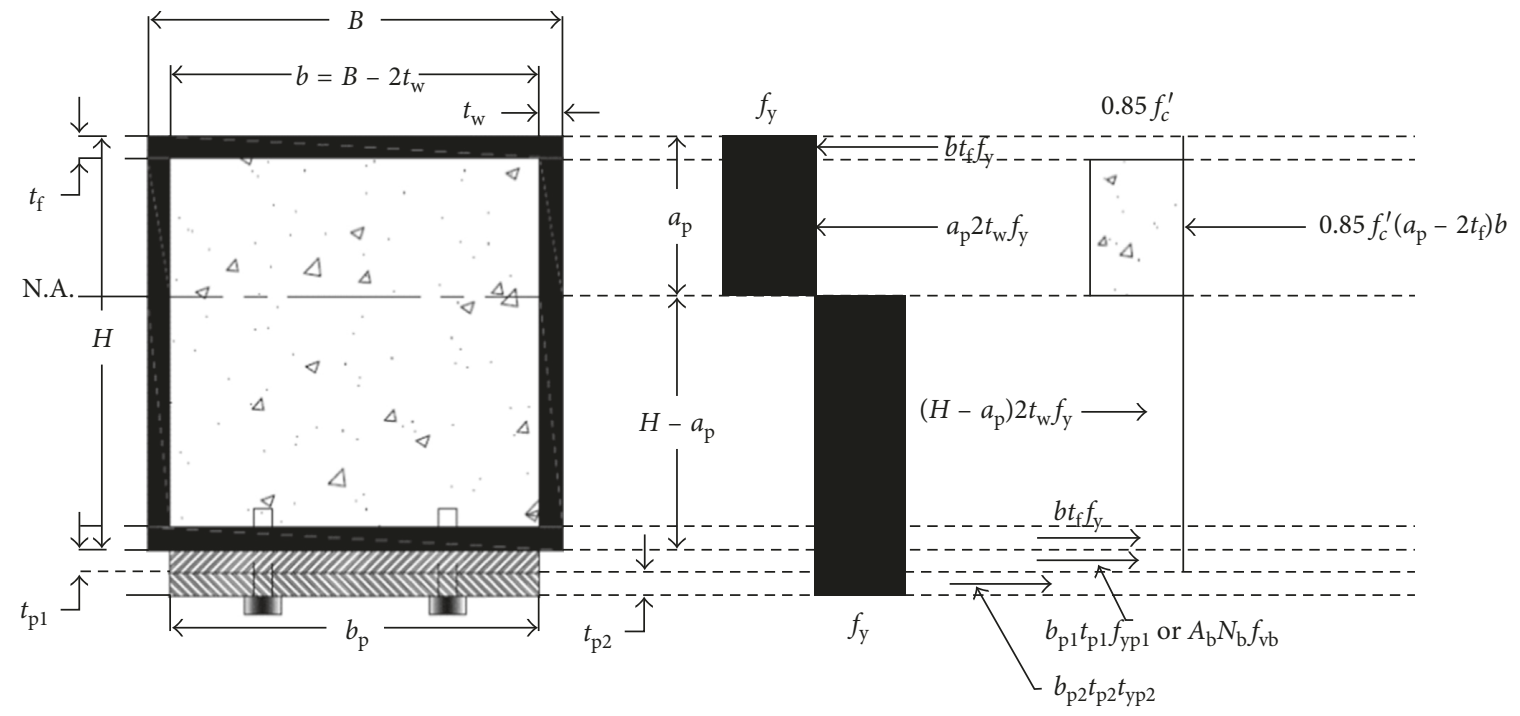

(c)

FIgURE 15: Theoretical model for calculating the ultimate moment capacity. (a) Stress blocks and forces for group A beams. (b) Stress blocks and forces for group B beams. (c) Stress blocks and forces for group C beams. 
Hence, it ensures that the SSCFST beam and the retrofitted external steel plates can achieve a ductile behaviour. Therefore, the tension or compression forces obtained from the bottom or top external steel plates can be predicted based on the yielding tensile stress of the steel plates as follows:

$$
F_{\mathrm{p}}=f_{\mathrm{yp}} A_{\mathrm{gp}},
$$

where $F_{\mathrm{p}}$ is the force in the external steel plates and $f_{\mathrm{yp}}$ and $A_{\mathrm{gp}}$ are the yielding stress and cross-sectional area of the external steel plates, respectively.

The above equation was found to be convenient for computing the ultimate moment capacity of SCCFST beams retrofitted with external steel plates using grade 12.9 bolts (bolts with the higher strength). However, for SCCFST beams retrofitted with external steel plates using grade 8.8 bolts (bolts with the lower strength), another condition was considered for the steel plates on the tension side (bottom steel plates). For steel plates in tension with grade 8.8 bolts, the most control criteria are the shear strength of the fixing bolts rather than the yielding strength of the steel plates. So that, the expected tension forces obtained from the bottom external steel plates can be predicted based on the shear strength of the fixing bolts as follows:

$$
F_{\mathrm{b}}=f_{\mathrm{nv}} A_{\mathrm{b}} N_{\mathrm{b}}
$$

where $F_{\mathrm{b}}$ is the force in the external bottom steel plates and $f_{\mathrm{nv}}, A_{\mathrm{b}}$, and $N_{\mathrm{b}}$ are the shearing stress, cross-sectional area, and number of the bolts, respectively.

Figures 15(a)-15(c) illustrate the stress blocks and forces of the concrete and steel at the ultimate loading stage for the three different retrofitting schemes, single bottom plate, top and bottom plates, and double bottom plates, respectively. The depth of the neutral axis $\left(a_{\mathrm{p}}\right)$ from the compression face is computed by achieving axial force equilibrium over the cross section. The plastic moment capacity $\left(M_{\mathrm{p}}\right)$ is computed as the summation of bending moments caused by the concrete and steel forces around the neutral axis location $\left(a_{\mathrm{p}}\right)$. The obtaining equations for calculating $a_{\mathrm{p}}$ and $M_{\mathrm{p}}$ are given below for the three different retrofitting schemes:

(a) For retrofitted SCCFST beams using external single bottom steel plate (group A) with grade 12.9 bolts, $a_{\mathrm{p}}$ and $M_{\mathrm{p}}$ can be calculated as follows:

$$
\begin{aligned}
a_{\mathrm{p}}= & \frac{2 f_{\mathrm{y}} H t_{\mathrm{w}}+f_{\mathrm{yp}} b_{\mathrm{p}} t_{\mathrm{p}}+0.85 f_{\mathrm{c}}^{\prime} b t_{\mathrm{f}}}{4 f_{\mathrm{y}} t_{\mathrm{w}}+0.85 f_{\mathrm{c}}^{\prime} b}, \\
M_{\mathrm{p}}= & f_{\mathrm{y}} b t_{\mathrm{f}}\left(H-t_{\mathrm{f}}\right)+f_{\mathrm{y}} t_{w}\left(H-a_{\mathrm{p}}\right)^{2}+f_{\mathrm{y}} t_{\mathrm{w}} a_{\mathrm{p}}^{2} \\
& +\frac{0.85}{2} f_{\mathrm{c}}^{\prime} b\left(a_{\mathrm{p}}-t_{\mathrm{f}}\right)^{2}+f_{\mathrm{yp}} b_{\mathrm{p}} t_{\mathrm{p}}\left(H-a_{\mathrm{p}}+\frac{t_{\mathrm{p}}}{2}\right) .
\end{aligned}
$$

(b) For retrofitted SCCFST beams using external single bottom steel plate (group A) with grade 8.8 bolts, $a_{\mathrm{p}}$ and $M_{\mathrm{p}}$ can be calculated as follows:

$$
\begin{aligned}
a_{\mathrm{p}}= & \frac{2 f_{\mathrm{y}} H t_{\mathrm{w}}+f_{\mathrm{nv}} A_{\mathrm{b}} N_{\mathrm{b}}+0.85 f_{\mathrm{c}}^{\prime} b t_{\mathrm{f}}}{4 f_{\mathrm{y}} t_{\mathrm{w}}+0.85 f_{\mathrm{c}}^{\prime} b} \\
M_{\mathrm{p}}= & f_{\mathrm{y}} b t_{\mathrm{f}}\left(H-t_{\mathrm{f}}\right)+f_{\mathrm{y}} t_{\mathrm{w}}\left(H-a_{\mathrm{p}}\right)^{2}+f_{\mathrm{y}} t_{\mathrm{w}} a_{\mathrm{p}}^{2} \\
& +\frac{0.85}{2} f_{\mathrm{c}}^{\prime} b\left(a_{\mathrm{p}}-t_{\mathrm{f}}\right)^{2}+f_{\mathrm{nv}} A_{\mathrm{b}} N_{\mathrm{b}}\left(H-a_{\mathrm{p}}+\frac{t_{\mathrm{p}}}{2}\right) .
\end{aligned}
$$

(c) For retrofitted SCCFST beams using external top and bottom steel plates (group B) with grade 12.9 bolts, $a_{\mathrm{p}}$ and $M_{\mathrm{p}}$ can be calculated as follows:

$$
\begin{aligned}
a_{p}= & \frac{2 f_{\mathrm{y}} H t_{\mathrm{w}}+0.85 f_{\mathrm{c}}^{\prime} b t_{\mathrm{f}}}{4 f_{\mathrm{y}} t_{\mathrm{w}}+0.85 f_{\mathrm{c}}^{\prime} b}, \\
M_{\mathrm{p}}= & f_{\mathrm{y}} b t_{\mathrm{f}}\left(H-t_{\mathrm{f}}\right)+f_{\mathrm{y}} t_{\mathrm{w}}\left(H-a_{\mathrm{p}}\right)^{2}+f_{\mathrm{y}} t_{\mathrm{w}} a_{\mathrm{p}}^{2} \\
& +\frac{0.85}{2} f_{\mathrm{c}}^{\prime} b\left(a_{\mathrm{p}}-t_{\mathrm{f}}\right)^{2}+f_{\mathrm{yp}} b_{\mathrm{p}} t_{\mathrm{p}}\left(H-a_{\mathrm{p}}+\frac{t_{\mathrm{p}}}{2}\right) \\
& +f_{\mathrm{yp}} b_{\mathrm{p}} t_{\mathrm{p}}\left(a_{\mathrm{p}}+\frac{t_{\mathrm{p}}}{2}\right) .
\end{aligned}
$$

(d) For retrofitted SCCFST beams using external top and bottom steel plates (group B) with grade 8.8 bolts, $a_{\mathrm{p}}$ and $M_{\mathrm{p}}$ can be calculated as follows:

$$
\begin{aligned}
a_{\mathrm{p}}= & \frac{2 f_{\mathrm{y}} H t_{\mathrm{w}}+f_{\mathrm{nv}} A_{\mathrm{b}} N_{\mathrm{b}}-f_{\mathrm{yp}} b_{\mathrm{p}} t_{\mathrm{p}}+0.85 f_{\mathrm{c}}^{\prime} b t_{\mathrm{f}}}{4 f_{\mathrm{y}} t_{\mathrm{w}}+0.85 f_{\mathrm{c}}^{\prime} b}, \\
M_{\mathrm{p}}= & f_{\mathrm{y}} b t_{\mathrm{f}}\left(H-t_{\mathrm{f}}\right)+f_{\mathrm{y}} t_{\mathrm{w}}\left(H-a_{\mathrm{p}}\right)^{2}+f_{\mathrm{y}} t_{\mathrm{w}} a_{\mathrm{p}}^{2} \\
& +\frac{0.85}{2} f_{\mathrm{c}}^{\prime} b\left(a_{\mathrm{p}}-t_{\mathrm{f}}\right)^{2}+f_{\mathrm{nv}} A_{\mathrm{b}} N_{\mathrm{b}}\left(H-a_{\mathrm{p}}\right) \\
& +f_{\mathrm{yp}} b_{\mathrm{p}} t_{\mathrm{p}}\left(a_{\mathrm{p}}+\frac{t_{\mathrm{p}}}{2}\right) .
\end{aligned}
$$

(e) For retrofitted SCCFST beams using external double bottom steel plates (group C) with grade 12.9 bolts, $a_{\mathrm{p}}$ and $M_{\mathrm{p}}$ can be calculated as follows:

$$
\begin{aligned}
a_{\mathrm{p}}= & \frac{2 f_{\mathrm{y}} H t_{\mathrm{w}}+f_{\mathrm{yp} 1} b_{\mathrm{p} 1} t_{\mathrm{p} 1}+f_{\mathrm{yp} 2} b_{\mathrm{p} 2} t_{\mathrm{p} 2}+0.85 f_{\mathrm{c}}^{\prime} b t_{\mathrm{f}}}{4 f_{\mathrm{y}} t_{\mathrm{w}}+0.85 f_{\mathrm{c}}^{\prime} b}, \\
M_{\mathrm{p}}= & f_{\mathrm{y}} b t_{\mathrm{f}}\left(H-t_{\mathrm{f}}\right)+f_{\mathrm{y}} t_{\mathrm{w}}\left(H-a_{\mathrm{p}}\right)^{2}+f_{\mathrm{y}} t_{\mathrm{w}} a_{\mathrm{p}}^{2} \\
& +\frac{0.85}{2} f_{\mathrm{c}}^{\prime} b\left(a_{\mathrm{p}}-t_{\mathrm{f}}\right)^{2}+f_{\mathrm{yp} 1} b_{\mathrm{p} 1} t_{\mathrm{p} 1}\left(H-a_{\mathrm{p}}+\frac{t_{\mathrm{p} 1}}{2}\right) \\
& +f_{\mathrm{yp} 2} b_{\mathrm{p} 2} t_{\mathrm{p} 2}\left(H-a_{\mathrm{p}}+t_{\mathrm{p} 1}+\frac{t_{\mathrm{p} 2}}{2}\right) .
\end{aligned}
$$


TABLe 9: Comparisons of experimental moment capacities against the theoretical model and design code values.

\begin{tabular}{|c|c|c|c|c|c|c|}
\hline Group name & Designation of beams & $M_{\mathrm{ue}}(\mathrm{kN} \cdot \mathrm{m})$ & $M_{\mathrm{ua}}(\mathrm{kN} \cdot \mathrm{m})$ & $M_{\mathrm{ua}} / M_{\mathrm{ue}}$ & $M_{\mathrm{uc}}(\mathrm{kN} \cdot \mathrm{m})$ & $M_{\mathrm{uc}} / M_{\mathrm{ue}}$ \\
\hline \multirow{7}{*}{ Group A (single bottom plate) } & CB-A & 17.04 & 14.39 & 0.844 & 14.39 & 0.844 \\
\hline & IB-PL-SB & 16.99 & 17.41 & 1.025 & 14.39 & 0.847 \\
\hline & IB-FL-SB & 18.69 & 19.13 & 1.024 & 14.39 & 0.770 \\
\hline & RB-PL-SB & 17.20 & 16.43 & 0.955 & 14.39 & 0.837 \\
\hline & RB-FL-SB & 21.61 & 20.54 & 0.950 & 14.39 & 0.666 \\
\hline & Mean & & & 0.960 & & 0.793 \\
\hline & $\mathrm{SD}$ & & & 0.074 & & 0.078 \\
\hline \multirow{7}{*}{ Group B (top and bottom plates) } & CB-B & 17.04 & 14.45 & 0.848 & 14.45 & 0.848 \\
\hline & IB-PL-TB & 17.57 & 18.46 & 1.051 & 14.45 & 0.822 \\
\hline & IB-FL-TB & 20.84 & 21.89 & 1.050 & 14.45 & 0.693 \\
\hline & RB-PL-TB & 17.92 & 17.15 & 0.957 & 14.45 & 0.806 \\
\hline & RB-FL-TB & 24.80 & 23.82 & 0.960 & 14.45 & 0.583 \\
\hline & Mean & & & 0.973 & & 0.751 \\
\hline & SD & & & 0.084 & & 0.111 \\
\hline \multirow{7}{*}{ Group C (double bottom plates) } & $\mathrm{CB}-\mathrm{C}$ & 17.04 & 14.29 & 0.839 & 14.29 & 0.839 \\
\hline & IB-PL-DB & 17.47 & 16.86 & 0.965 & 14.29 & 0.818 \\
\hline & IB-FL-DB & 19.60 & 18.94 & 0.966 & 14.29 & 0.729 \\
\hline & RB-PL-DB & 17.21 & 18.39 & 1.069 & 14.29 & 0.830 \\
\hline & RB-FL-DB & 23.13 & 24.85 & 1.074 & 14.29 & 0.618 \\
\hline & Mean & & & 0.983 & & 0.767 \\
\hline & SD & & & 0.096 & & 0.094 \\
\hline \multirow{2}{*}{ Total } & Mean & & & 0.972 & & 0.770 \\
\hline & SD & & & 0.079 & & 0.090 \\
\hline
\end{tabular}

(f) For retrofitted SCCFST beams using external top and bottom steel plates (group C) with grade 8.8 bolts, $a_{\mathrm{p}}$ and $M_{\mathrm{p}}$ can be calculated as follows:

$$
\begin{aligned}
a_{\mathrm{p}}= & \frac{2 f_{\mathrm{y}} H t_{\mathrm{w}}+f_{\mathrm{nv}} A_{\mathrm{b}} N_{\mathrm{b}}+0.85 f_{\mathrm{c}}^{\prime} b t_{\mathrm{f}}}{4 f_{\mathrm{y}} t_{\mathrm{w}}+0.85 f_{\mathrm{c}}^{\prime} b}, \\
M_{\mathrm{p}}= & f_{\mathrm{y}} b t_{\mathrm{f}}\left(H-t_{\mathrm{f}}\right)+f_{\mathrm{y}} t_{\mathrm{w}}\left(H-a_{\mathrm{p}}\right)^{2}+f_{\mathrm{y}} t_{\mathrm{w}} a_{\mathrm{p}}^{2} \\
& +\frac{0.85}{2} f_{\mathrm{c}}^{\prime} b\left(a_{\mathrm{p}}-t_{\mathrm{f}}\right)^{2}+f_{\mathrm{nv}} A_{\mathrm{b}} N_{\mathrm{b}}\left(H-a_{\mathrm{p}}\right) .
\end{aligned}
$$

Finally, regarding the SCCFST beams retrofitted using partial length steel plates for the three different retrofitting schemes (groups A, B, and C). The experimental test results revealed that partial length retrofitting scheme (beams retrofitted along their pure bending zone only) has an inconsiderable effect on the ultimate moment capacity. Therefore, the plastic moment capacity $\left(M_{p}\right)$ of these SCCFST beams is calculated based on $M_{\mathrm{p}}$ calculated according to the previously mentioned equations multiplied by a reduction factor of 0.91 and 0.8 , for beams in group A with bolt grades 8.8 and 12.9 , respectively. For beams in group $\mathrm{B}$, the reduction factors are equal to 0.84 and 0.72 . However, for the group $\mathrm{C}$ beams, the reduction factors are 0.89 and 0.74 , for beams retrofitted by steel plates with bolt grades 8.8 and 12.9 , respectively. These reduction factors were estimated based on the experimental test results obtained from this study.

5.1. Test Results against the Theoretical Model and Design Code. The predicted flexural capacities $\left(M_{\mathrm{ua}}\right)$ of the retrofitted SCCFST beams utilizing the aforementioned developed theoretical model and the American specification AISC 360-10 method $\left(M_{\mathrm{uc}}\right)$ are compared with the current experimental results $\left(M_{\mathrm{ue}}\right)$ as shown in Table 9. Furthermore, the mean value and the standard deviation (SD) of the ratios $M_{\mathrm{ua}} / M_{\mathrm{ue}}$ and $M_{\mathrm{uc}} / M_{\mathrm{ue}}$ are listed in Table 9.

The results in Table 9 revealed that the developed model in this study could predict the ultimate moment capacity of retrofitted SCCFST beams accurately. On the other hand, the results indicated that the AISC 360-10 model underestimates (conservative) the ultimate moment capacity of these beams. This underestimation is expected because the AISC 360-10 model did not take into consideration the effect of external steel plates on the flexural strength of retrofitted SCCFST beams. However, the new theoretical model which is suggested in this study includes the influence of these bolted steel plates.

For instance, the theoretical model was able to predict the moment capacity of retrofitted SCCFST beams of group A with an average value of 0.960 and with a standard deviation (SD) of 0.074 . On the other hand, the AISC 360-10 code underestimated the moment capacity by an average of about $21 \%$ and with SD equal to 0.078 . Similarly, regarding the retrofitted beams of group $B$, the theoretical model predicted the moment capacity with an average value of 0.973 and with a SD of 0.084. However, the AISC 360-10 code underestimated the moment capacity by an average of about $25 \%$ and with SD equal to 0.078 . Finally, the theoretical model gave an average estimation of about 0.983 and with a SD of 0.096 for retrofitted beams within group C. While, the AISC 360-10 specification again underestimated the moment resistance of retrofitted beams by about $23 \%$.

It is worth to note that the AISC $360-10$ method can predict the moment capacity of SCCFST beams retrofitted with partial length steel plate and with lower bolt strength, 
more accurately than beams retrofitted with full-length plates and with higher strength bolts. For example, the AISC 360-10 method estimated the flexural strength of beams IB-PL-SB, IB-PL-TB, and IB-PL-DB, with an average underestimation of $17 \%$. However, regarding beams RB-FL-SB, RB-FL-TB, and RB-FL-DB, the level of conservation was about $38 \%$.

Finally, comparison results indicated that the moment capacity of beams retrofitted using partial length steel plates could be computed by neglecting the effect of the bolted steel plates. It is clear that when the SCCFST beams retrofitted with steel plates along their partial length (along with the constant bending zone span) only, the enhancement in ultimate moment capacity is indeed insignificant. So that, both the theoretical model of this study and the AISC 360-10 model can be used to estimate the moment resistance of such retrofitted beams.

\section{Conclusions}

This paper highlights the results of an experimental study investigating the flexural performance of SCCFST beams retrofitted using externally bolted steel plates with three different schemes including varied configurations. The moment capacities, ductility, failure modes, and momentdeflection curves of beam specimens were reported and discussed. Based on the experimental results and observations, the following conclusions can be stated:

(i) The typical failure modes of the fully retrofitted SCCFST beams were characterized by outward local buckling of the beam top steel flange, ruptures of some of their anchoring bolts within the beam shear span, delamination and separation of the attached retrofitting plates, and finally rupture failure of the tension bottom flanges.

(ii) Different failure modes were observed for SCCFST beams which retrofitted by top and bottom steel plates (group B), compared to their counterparts in other groups. The basic difference was that no local buckling was recognized at the top steel flange of all the beams. Furthermore, an upward local buckling appeared at the top retrofitting steel plate of the beam RB-FL-TB.

(iii) The moment versus midspan deflection curves of the control and retrofitted SCCFST beams in all groups showed elastic behaviour at the first stage of loading. Then, the curves follow an inelastic path with a gradual reduction in stiffness until reaching the maximum bending capacity.

(iv) Test results revealed that the percentage increase in the ultimate moment capacity due to the retrofitting of SCCFST beams using the different three schemes ranged from $1.00 \%$ to $46.00 \%$. It is worth to note that retrofitting scheme of group B beams (top and bottom bolted steel plates) was the most efficient technique regarding the flexural strength enhancement.

(v) The relative ductility index (RDI) results indicated that all the retrofitted beams were able to restore about $35 \%$ to $75 \%$ of the original ductility of the control beams. However, the most effective retrofitting method regarding ductility recovering was the retrofitting scheme of group B (top and bottom bolted steel plates).

(vi) It was found that the full retrofitting scheme (steel plates applied along the entire beam length) is much efficient than the partial retrofitting scheme (steel plates applied along constant bending zone only) regarding improving the ultimate moment resistance, stiffness, and ductility capacity of the retrofitted beams.

(vii) A new theoretical model based on the AISC 360-10 method was developed. The new model is developed in such a way to take into consideration the effect of external retrofitting steel plates on the prediction of the ultimate moment capacity of SCCFST beams. The comparison results revealed that this model could predict the ultimate moment capacity of retrofitted SCCFST beams accurately with a total average of $97 \%$.

(viii) Finally, it can be concluded that all the adopted retrofitting schemes were effective in restoring the flexural strength and ductility of the damaged beams and even enhance the ultimate flexural strength, especially for beams retrofitted along their full span length with top and bottom plates.

\section{Conflicts of Interest}

The authors declare that they have no conflicts of interest.

\section{Acknowledgments}

The authors acknowledge the financial support of the Scientific Research Unit of the University of Gaziantep on the Project MF 14.05. The authors also would like to thank the valuable support of the BASF/Turkey (AKAS) in supplying the concrete admixtures.

\section{References}

[1] Z.-B. Wang, Z. Tao, L.-H. Han, B. Uy, D. Lam, and W.-H. Kang, "Strength, stiffness and ductility of concretefilled steel columns under axial compression," Engineering Structures, vol. 135, pp. 209-221, 2017.

[2] M. Elchalakani, A. Karrech, M. F. Hassanein, and B. Yang, "Plastic and yield slenderness limits for circular concrete filled tubes subjected to static pure bending," Thin-Walled Structures, vol. 109, pp. 50-64, 2016.

[3] Z. Lai, A. H. Varma, and K. Zhang, "Noncompact and slender rectangular CFT members: experimental database, analysis, and design," Journal of Constructional Steel Research, vol. 101, pp. 455-468, 2014.

[4] G. Li, D. Liu, Z. Yang, and C. Zhang, "Flexural behavior of high strength concrete filled high strength square steel tube," Journal of Constructional Steel Research, vol. 128, pp. 732-744, 2017.

[5] M. V Chitawadagi and M. C. Narasimhan, "Strength deformation behaviour of circular concrete filled steel tubes subjected to pure bending," Journal of Constructional Steel Research, vol. 65, no. 8-9, pp. 1836-1845, 2009. 
[6] L.-H. Han, W. Li, and R. Bjorhovde, "Developments and advanced applications of concrete-filled steel tubular (CFST) structures: members," Journal of Constructional Steel Research, vol. 100, pp. 211-228, 2014.

[7] H. Abbas, Y. Al-Salloum, S. Alsayed, M. Alhaddad, and R. Iqbal, "Post-heating response of concrete-filled circular steel columns," KSCE Journal of Civil Engineering, vol. 21, no. 4, pp. 1367-1378, 2017.

[8] L.-H. Han, H. Lu, G.-H. Yao, and F.-Y. Liao, "Further study on the flexural behaviour of concrete-filled steel tubes," Journal of Constructional Steel Research, vol. 62, no. 6, pp. 554-565, 2006.

[9] M. Mahgub, A. Ashour, D. Lam, and X. Dai, "Tests of selfcompacting concrete filled elliptical steel tube columns," ThinWalled Structures, vol. 110, pp. 27-34, 2017.

[10] P. Kumar, K. Sudalaimani, and M. Shanmugasundaram, “An investigation on self-compacting concrete using ultrafine natural steatite powder as replacement to cement," Advances in Materials Science and Engineering, vol. 2017, Article ID 8949041, 8 pages, 2017.

[11] M. Lachemi, K. M. A. Hossain, and V. B. Lambros, “Axial load behavior of self-consolidating concrete-filled steel tube columns in construction and service stages," ACI Structural Journal, vol. 103, no. 1, p. 38, 2006.

[12] B. J. M. AL-Eliwi, T. Ekmekyapar, R. H. Faraj, M. T. Göğüş, and A. A. M. AL-Shaar, "Performance of lightweight aggregate and self-compacted concrete-filled steel tube columns," Steel and Composite Structures, vol. 25, no. 3, pp. 299-314, 2017.

[13] L.-H. Han and G.-H. Yao, "Experimental behaviour of thinwalled hollow structural steel (HSS) columns filled with selfconsolidating concrete (SCC)," Thin-Walled Structures, vol. 42, no. 9, pp. 1357-1377, 2004.

[14] L.-H. Han, G.-H. Yao, and X.-L. Zhao, "Tests and calculations for hollow structural steel (HSS) stub columns filled with selfconsolidating concrete (SCC)," Journal of Constructional Steel Research, vol. 61, no. 9, pp. 1241-1269, 2005.

[15] Y. T. Obaidat, S. Heyden, O. Dahlblom, G. Abu-Farsakh, and Y. Abdel-Jawad, "Retrofitting of reinforced concrete beams using composite laminates," Construction and Building Materials, vol. 25, no. 2, pp. 591-597, 2011.

[16] C.-J. Jiang, Z.-D. Lu, and L.-Z. Li, "Shear performance of firedamaged reinforced concrete beams repaired by a bolted sideplating technique," Journal of Structural Engineering, vol. 143, no. 5, p. 4017007, 2017.

[17] J. Peng, H. Tang, and J. Zhang, "Structural behavior of corroded reinforced concrete beams strengthened with steel plate," Journal of Performance of Constructed Facilities, vol. 31, no. 4, p. 4017013, 2017.

[18] F. Sevuk and G. Arslan, "Retrofit of damaged reinforced concrete beams by using steel plate," in Proceedings of the Structures Congress 2005: Metropolis and Beyond, pp. 1-8, New York, NY, USA, April 2005.

[19] Z.-B. Wang, Q. Yu, and Z. Tao, "Behaviour of CFRP externally-reinforced circular CFST members under combined tension and bending," Journal of Constructional Steel Research, vol. 106, pp. 122-137, 2015.

[20] M. C. Sundarraja and G. G. Prabhu, "Finite element modelling of CFRP jacketed CFST members under flexural loading," Thin-Walled Structures, vol. 49, no. 12, pp. 1483-1491, 2011.

[21] A. W. Al Zand, W. H. W. Badaruzzaman, A. A. Mutalib, and S. J. Hilo, "The enhanced performance of CFST beams using different strengthening schemes involving unidirectional CFRP sheets: an experimental study," Engineering Structures, vol. 128, pp. 184-198, 2016.
[22] S. Aykac, I. Kalkan, B. Aykac, S. Karahan, and S. Kayar, "Strengthening and repair of reinforced concrete beams using external steel plates," Journal of Structural Engineering, vol. 139, no. 6, pp. 929-939, 2012.

[23] R. A. Barnes, P. S. Baglin, G. C. Mays, and N. K. Subedi, "External steel plate systems for the shear strengthening of reinforced concrete beams," Engineering Structures, vol. 23, no. 9, pp. 1162-1176, 2001.

[24] X. Xu, Z. Lu, L. Li, and C. Jiang, "Numerical study on the local buckling behaviour of bolted steel plates in steel jacketing," Advances in Materials Science and Engineering, vol. 2017, Article ID 1352084, 15 pages, 2017.

[25] T. A. El-Maaddawy, "Mechanically fastened composites for retrofitting corrosion-damaged reinforced-concrete beams: experimental investigation," Journal of Composites for Construction, vol. 18, no. 2, p. 4013041, 2013.

[26] Y. Guan, B. Jiang, and Y. Jiang, "Experimental study on RC beams strengthened in shear with the FRP-bolt strengthening technology," in Proceedings of the Design, Construction, Rehabilitation, and Maintenance of Bridges, pp. 57-64, Hunan, China, June 2011.

[27] M. Sundarraja and G. Prabhu, "Experimental investigation on strengthening of CFST members under flexure using CFRP fabric," Arabian Journal for Science and Engineering, vol. 39, no. 2, pp. 659-668, 2014.

[28] N. Yazdani, F. Haque, and I. Hasan, "Flexural and shear behavior of FRP strengthened AASHTO type concrete bridge girders," Journal of Engineering, vol. 2016, Article ID 5201910, 10 pages, 2016.

[29] J. Vercher, E. Gil, Á. Mas, C. Lerma, and M. E. Torner, "Flexural strengthening of damaged T-joists with severe corrosion using CFRP sheets," Advances in Materials Science and Engineering, vol. 2017, Article ID 6030357, 9 pages, 2017.

[30] A. Alfeehan, "Strengthening of RC beams by external steel plate using mechanical connection technique," Journal of Engineering and Development, vol. 18, no. 1, pp. 202-215, 2014.

[31] R. K. L. Su and Y. Zhu, "Experimental and numerical studies of external steel plate strengthened reinforced concrete coupling beams," Engineering Structures, vol. 27, no. 10, pp. 1537-1550, 2005.

[32] R. K. L. Su, B. Cheng, L. Wang, W. H. Siu, and Y. Zhu, "Use of bolted steel plates for strengthening of reinforced concrete beams and columns," The IES Journal Part A: Civil \& Structural Engineering, vol. 4, no. 2, pp. 55-68, 2011.

[33] Y. Zhu and R. K. L. Su, "Behavior of strengthened reinforced concrete coupling beams by bolted steel plates, Part 2: evaluation of theoretical strength," Structural Engineering and Mechanics, vol. 34, no. 5, pp. 563-580, 2010.

[34] EFNARC, The European Guidelines for Self-Compacting Concrete, Specification, Production and Use, EFNARC, Europe, 2005.

[35] ASTM C39/C39M-14a, Standard Test Method for Compressive Strength of Cylindrical Concrete Specimens, ASTM International, West Conshohocken, PA, USA, 2014.

[36] ASTM E8/E8M-15a, Standard Test Methods for Tension Testing of Metallic Materials, ASTM International, West Conshohocken, PA, USA, 2015.

[37] J. Chen, J. Wang, F. Xie, and W. Jin, "Behavior of thin-walled dodecagonal section double skin concrete-filled steel tubes under bending," Thin-Walled Structures, vol. 98, pp. 293-300, 2016.

[38] AISC 360-10, Specification for Structural Steel Buildings, American Institute of Steel Construction (AISC), Chicago, IL, USA, 2010. 


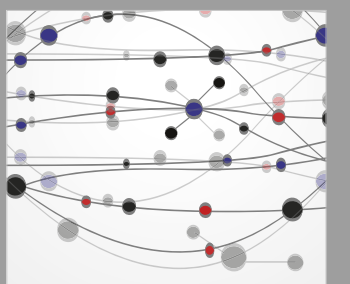

The Scientific World Journal
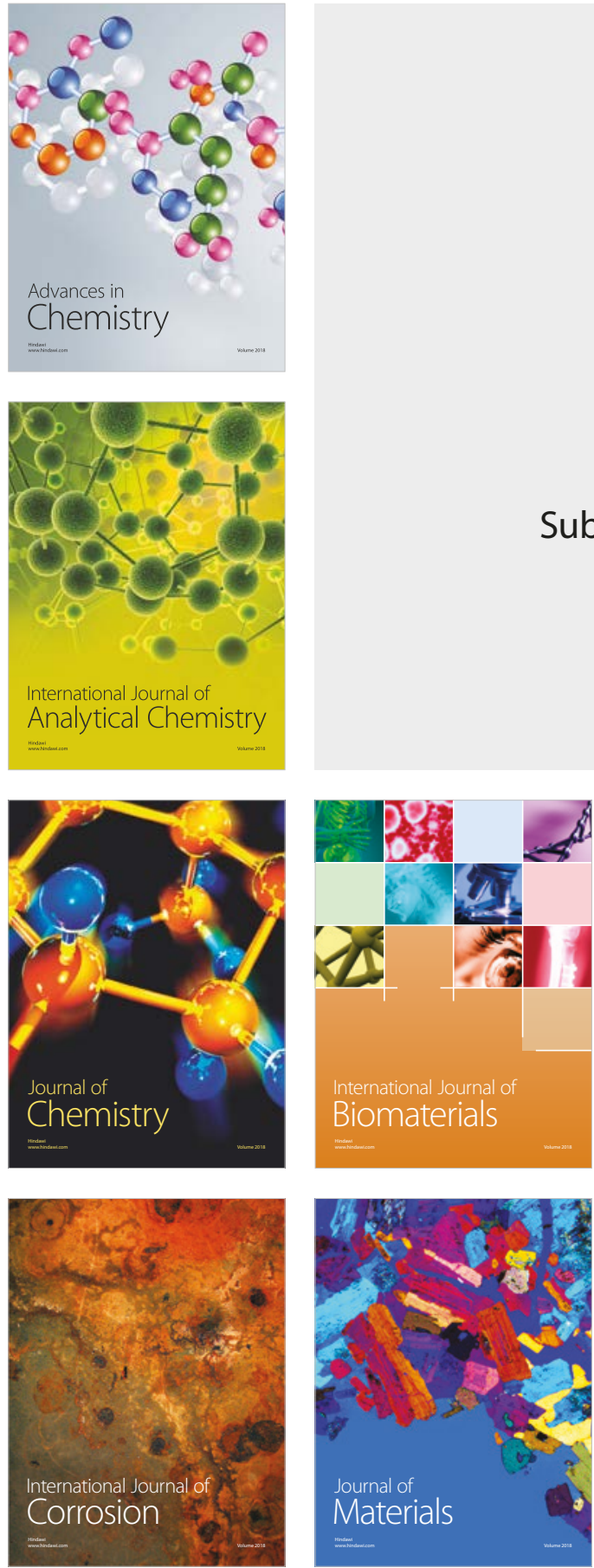

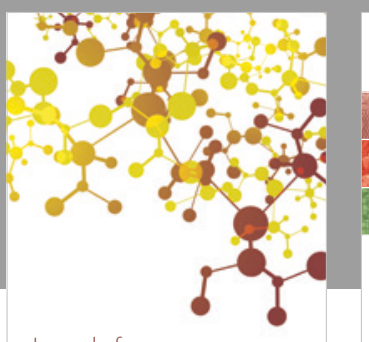

Journal of

Applied Chemistry
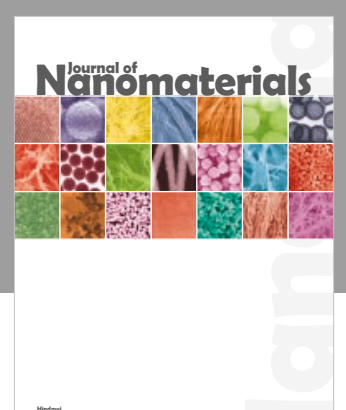

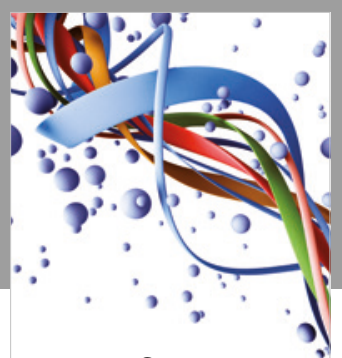

Scientifica

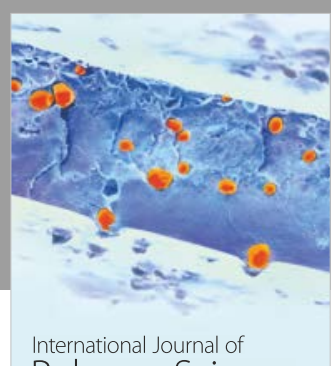

Polymer Science

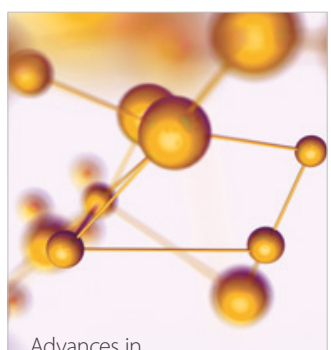

Physical Chemistry
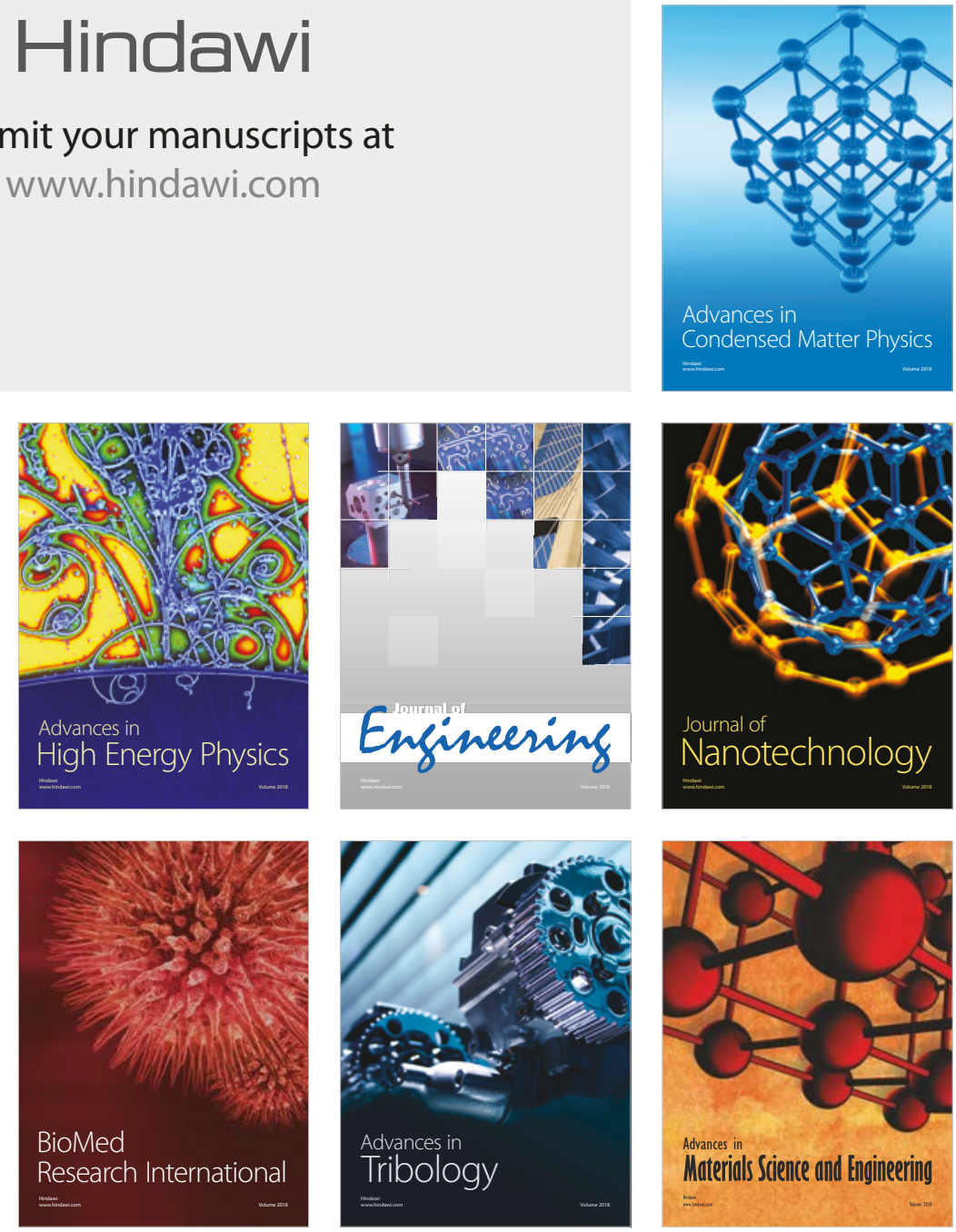